\title{
A novel mechanism for the anticancer activity of aspirin and salicylates
}

\author{
ASMA'U I.J. BASHIR $^{1}$, CHANDRA S. KANKIPATI ${ }^{1}$, SARAH JONES $^{2}$, ROBERT M. NEWMAN ${ }^{3}$, \\ STEPHEN T. SAFRANY ${ }^{4}$, CHRISTOPHER J. PERRY ${ }^{2}$ and IAIN D. NICHOLL ${ }^{1}$ \\ ${ }^{1}$ Department of Biomedical Science and Physiology, School of Sciences; ${ }^{2}$ School of Pharmacy; \\ ${ }^{3}$ School of Mathematics and Computer Science, Faculty of Science and Engineering, University of Wolverhampton, \\ Wolverhampton WV1 1LY, UK; ${ }^{4}$ School of Medicine, RCSI-Bahrain, Adliya, Kingdom of Bahrain
}

Received April 16, 2018; Accepted December 18, 2018

DOI: $10.3892 /$ ijo.2019.4701

\begin{abstract}
Epidemiological studies indicate that long-term aspirin usage reduces the incidence of colorectal cancer (CRC) and may protect against other non-CRC associated adenocarcinomas, including oesophageal cancer. A number of hypotheses have been proposed with respect to the molecular action of aspirin and other non-steroidal anti-inflammatory drugs in cancer development. The mechanism by which aspirin exhibits toxicity to CRC has been previously investigated by synthesising novel analogues and derivatives of aspirin in an effort to identify functionally significant moieties. Herein, an early effect of aspirin and aspirin-like analogues against the SW480 CRC cell line was investigated, with a particular focus on critical molecules in the epidermal growth factor (EGF) pathway. The present authors proposed that aspirin, diaspirin and analogues, and diflunisal (a salicylic acid derivative) may rapidly perturb EGF and EGF receptor (EGFR) internalisation. Upon longer incubations, the diaspirins and thioaspirins may inhibit EGFR phosphorylation at Tyr1045 and Tyr1173. It was additionally demonstrated, using a qualitative approach, that EGF internalisation in the SW480 cell line may be directed to endosomes by fumaryldiaspirin using early endosome antigen 1 as an early endosomal marker and that EGF internalisation may also be perturbed in oesophageal cell lines, suggestive of an effect not only restricted to CRC cells. Taken together and in light of our previous findings that the
\end{abstract}

Correspondence to: Dr Iain D. Nicholl, Department of Biomedical Science and Physiology, School of Sciences, Faculty of Science and Engineering, University of Wolverhampton, Wulfruna Street, Wolverhampton WV1 1LY, UK

E-mail: i.nicholl@wlv.ac.uk

Abbreviations: CRC, colorectal cancer; EEA1, early endosome antigen 1; MAPK, mitogen-activated protein kinase; NSAID, non-steroidal anti-inflammatory drug

Key words: epidermal growth factor, epidermal growth factor receptor, aspirin, colorectal cancer, endocytosis aspirin-like analogues can affect cyclin D1 expression and nuclear factor- $\kappa \mathrm{B}$ localisation, it was hypothesized that aspirin and aspirin analogues significantly and swiftly perturb the EGFR axis and that the protective activity of aspirin may in part be explained by perturbed EGFR internalisation and activation. These findings may also have implications in understanding the inhibitory effect of aspirin and salicylates on wound healing, given the critical role of EGF in the response to tissue trauma.

\section{Introduction}

A total of $\sim 600,000$ patients annually succumb to colorectal cancer (CRC) worldwide (1), with indications that the incidence is on the rise, particularly in Asia $(2,3)$ and possibly in the younger population in the USA (4). Regular aspirin intake significantly reduces the risk of developing CRC and other gastrointestinal tract malignancies $(5,6)$, which has caused debate regarding regular aspirin use as a chemopreventive agent on a population basis $(7,8)$. Aspirin usage following a diagnosis of colon cancer also has a positive outcome: Longer survival has been reported among patients with mutated-PIK3CA CRC, but not those with wild-type PIK3CA cancer (9).

Despite vigorous investigation, the molecular basis for the chemopreventive effect of aspirin remains controversial and a large number of molecular targets of aspirin and salicylates have been suggested (10). The molecular effects on cells and tissues include but are not limited to: Inhibition of cyclooxygenase (COX) activity (11-13) and protein phosphatase 2 enzymatic activity (14), inhibition of nuclear factor $(\mathrm{NF})-\kappa \mathrm{B}$ transcriptional activity (15), suppression of COX-2 gene transcription (16), inhibition of IкB kinase- $\beta$ (17), increased hMLH1 expression (18), selection for DNA microsatellite stability (19), altering mammalian target of rapamycin signalling (20) and a direct allosteric activation of AMP kinase (21). More recently, the breakdown product of aspirin, salicylate, has been demonstrated to inhibit CREB-binding protein/p300 acetyltransferase activity (22).

Therefore, it is reasonable to suggest that aspirin may act pleiotropically and there is some evidence that aspirin and other non-steroidal anti-inflammatory drug (NSAIDs) 
may also affect the epidermal growth factor (EGF) receptor (EGFR) axis. For example, metabolites of the NSAID sulindac can inhibit EGFR signalling through the inhibition of EGFR phosphorylation and decreased EGFR expression in HT29 colon cancer cells (23). A nitro-derivative of aspirin was demonstrated to inhibit EGFR signalling in human ovarian cancer cells (24). Furthermore, in COX-1-positive ovarian cancer cells cultured in vitro, aspirin inhibited EGF-associated protein kinase B (AKT) and extracellular signal-regulated kinase (ERK) phosphorylation (25).

In an attempt to better understand the toxicity of aspirin to CRC cells, a number of aspirin-like analogues were previously synthesised and diaspirins were identified as having the capacity to induce apoptosis in a CRC cell line (26), inhibit $\mathrm{NF}-\kappa \mathrm{B}$ in vitro and cyclin D1 expression, and suppress tumour growth in vivo in a murine model of $\mathrm{CRC}$ without evidence of apparent toxicity to the animal (27). The aim of the present study was to investigate whether aspirin and analogues, including fumaryldiaspirin (F-DiA), diflunisal and salicylates, which are common breakdown products of these compounds, are able to perturb EGF endocytosis in SW480 CRC cells (28), as these cells are known to express relatively high levels of wild type EGFR (29) compared with normal colonic epithelial primary cells, but exhibit decreased expression of COX-1 and negligible levels of COX-2 $(30,31)$. Given the role of EGF signalling in tissue repair (32), the findings of the present study may improve our understanding of the molecular basis of the action of aspirin as a chemopreventive agent and its inhibitory effect on wound healing.

\section{Materials and methods}

Chemicals and reagents. Foetal bovine serum (FBS) was purchased from PAA Laboratories (GE Healthcare Life Sciences, Little Chalfont, UK) or Labtech International, Ltd. (Heathfield, UK). Precision Plus Protein Colour standards and nitrocellulose were obtained from Bio-Rad Laboratories, Inc. (Hercules, CA, USA). Human recombinant EGF (PHG0313) was from Thermo Fisher Scientific, Inc. (Waltham, MA, USA). Alexa Fluor 555-EGF (E-35350) was from Molecular Probes; Thermo Fisher Scientific, Inc. EGFR (D38B1) XP ${ }^{\circledR}$ rabbit antibody (Alexa Fluor 488-conjugate; 1:100; cat. no. 5616) and EGFR rabbit antibody (D38B1; 1:100; cat. no. 4267) were from Cell Signaling Technology, Inc. (Danvers, MA, USA). Anti-early endosome antigen 1 (EEA1) antibody (1G11) Early Endosome Marker (ab70521; 1:1,000) was from Abcam (Cambridge, UK). Anti-GAPDH antibody (sc-25778; 1:1,000) was from Santa Cruz Biotechnology, Inc. (Dallas, TX, USA). VectaShield ${ }^{\circledR}$ mounting medium was from Vector Laboratories, Ltd. (Peterborough, UK). All other reagents were obtained from Sigma-Aldrich; Merck KGaA (Darmstadt, Germany), unless stated otherwise. Aspirin analogues, detailed in Table I, were synthesised in-house using previously described methods $(26,27)$.

Cell culture. Colon cancer adenocarcinoma SW480 cells were obtained from the European Collection of Authenticated Cell Cultures (Salisbury,UK) and cultured in LeibovitzL-15 medium (Thermo Fisher Scientific, Inc.) supplemented with 10\% (v/v) FBS supplemented with L-glutamine-penicillin-streptomycin
(Sigma-Aldrich; Merck KGaA). The OE33 and Flo-1 oesophageal cancer cell lines were a gift from Professor Tim Underwood (University of Southampton, Southampton, UK) and were cultured in Dulbecco's modified Eagle's medium high-glucose with phenol red (Thermo Fisher Scientific, Inc.) containing $10 \%$ (v/v) FBS supplemented with L-glutamine-penicillin-streptomycin (Sigma-Aldrich; Merck $\mathrm{KGaA}$ ). Cells were cultured in tissue culture flasks (Sarstedt, Inc., Newton, $\mathrm{NC}, \mathrm{USA}$ ) at $37^{\circ} \mathrm{C}$ in a humidified incubator with $5 \% \mathrm{CO}_{2}$, except for SW480 cells, which were cultured in the absence of $\mathrm{CO}_{2}$. Cells were regularly passaged at $70-80 \%$ confluence. The OE33 (also known as JROECL33) and Flo-1 cells are commercially available oesophageal cancer cell lines (33). The OE33 cell line expresses COX-2 and has been utilised to examine COX-2 inhibitors with respect to proliferation (34). Both cell lines express EGFR (35). Additionally, the cell lines were investigated as they were derived from oesophageal carcinomas, and thus represent a counterpoint to a colorectal adenocarcinoma (SW480). Another aim of the present study was to elucidate whether the sensitivity to the salicylates observed in the SW480 cell line was specific to a cell line of CRC origin only, given the reported chemopreventative activity of aspirin against oesophageal cancer; reviewed in $(36,37)$.

Cytotoxicity assay. Cell viability was assessed by MTT reduction assay (38) with modifications (39). Briefly, SW480 cells were seeded at a density of $10^{4}$ cell/well in a 96-well plate and incubated overnight at $37^{\circ} \mathrm{C}$. Following $24 \mathrm{~h}$, the culture medium was replaced with medium containing aspirin analogues (Table I) at 0.01, 0.03, 0.1, 0.3, 1 and $3 \mathrm{mM}$, and the cells were incubated at $37^{\circ} \mathrm{C}$ for a further $48 \mathrm{~h}$. A no-treatment control was included in these experiments. Following $48 \mathrm{~h}$ of incubation, the medium was aspirated from each well, the cells were washed once with fresh medium to remove drugs, and $300 \mu \mathrm{l}$ MTT reagent $(0.5 \mathrm{mg} / \mathrm{ml})$ was added. The cells were incubated at $37^{\circ} \mathrm{C}$ for $3 \mathrm{~h}$ and the solution was replaced with $200 \mu \mathrm{l}$ dimethyl sulphoxide (DMSO). The plates were incubated at $37^{\circ} \mathrm{C}$ for a further $30 \mathrm{~min}$ and the conversion of MTT into formazan crystals was measured by recording changes in absorbance at $540 \mathrm{~nm}$ in a Multiskan Ascent microplate reader (Thermo Fisher Scientific, Inc.). The plates were protected from light throughout the procedure. Drug dosage ranged from 0 to $3 \mathrm{mM}$. GraphPad Prism 7 (GraphPad Software, Inc., La Jolla, CA, USA) was used to plot dose-response curves and to determine half maximal inhibitory concentration $\left(\mathrm{IC}_{50}\right)$ values. All assays were performed in duplicates ( $\mathrm{n}=3$ experiments) and viable cells were expressed as the percentage relative to the negative control: Cell viability $=$ [absorbance $540 \mathrm{~nm}$ (treated cells-blank)/absorbance $540 \mathrm{~nm}$ (control cells-blank)]x100.

Immunoblot analysis. Cells $\left(5 \times 10^{4}\right)$ were plated in 6 -well tissue culture plates and incubated overnight at $37^{\circ} \mathrm{C}$. Cells incubated with compounds (Table I) for the times stated were washed with ice-cold PBS at $4^{\circ} \mathrm{C}$, gently scraped and suspended in $2 \mathrm{X}$ Laemmli sample buffer containing $10 \% \beta$-mercaptoethanol (40) and $0.01 \%$ protease inhibitor cocktail (100X; 5871S; CST Biological Reagents Co., Ltd., Shanghai, China). The samples were then heated to $100^{\circ} \mathrm{C}$ for $20 \mathrm{~min}$, centrifuged (18,000 x g; $5 \mathrm{~min}$; room temperature), 
Table I. List of compounds.

\begin{tabular}{|c|c|c|c|c|}
\hline Common name, synonym & Chemical, formal name & Laboratory number & $\mathrm{IC}_{50}(\mathrm{mM})$ & Source \\
\hline Salicylic acid, SA & 2-hydroxybenzoic acid & Not applicable & 2.6 & Commercially available \\
\hline Aspirin, ortho-aspirin & $\begin{array}{l}\text { 2-acetoxybenzoic acid, } \\
\text { acetylsalicylic acid }\end{array}$ & PN502 & 1.8 & Commercially available \\
\hline Diaspirin, DiA & Bis-carboxyphenylsuccinate & PN508 & 0.8 & (27) \\
\hline Fumaryldiaspirin, F-DiA & Bis-carboxyphenylfumarate & PN517 & 0.2 & (27) \\
\hline Not applicable & $m$-bromobenzoylsalicylic acid & PN524 & 0.4 & (27) \\
\hline Not applicable & Isopropyl $m$-bromobenzoylsalicylate & PN529 & ND & $(27)$ \\
\hline meta-aspirin & 3-acetoxybenzoic acid & PN548 & 3.8 & Synthesised in this study \\
\hline para-aspirin & 4-acetoxybenzoic acid & PN549 & 4.9 & Synthesised in this study \\
\hline Thioaspirin, ortho-TASP & 2-acetylthiobenzoic acid & PN590 & 0.2 & Synthesised in this study \\
\hline$m$-thioaspirin, meta-TASP & 3-acetylthiobenzoic acid & PN591 & 0.5 & Synthesised in this study \\
\hline p-thioaspirin, para-TASP & 4-acetylthiobenzoic acid & PN592 & 0.8 & Synthesised in this study \\
\hline Diflunisal, DIF & 5-(2,4-difluorophenyl) salicylic acid & Not applicable & 0.08 & Commercially available \\
\hline
\end{tabular}

$\mathrm{IC}_{50}$, half maximal inhibitory concentration; ND, not determined.

analysed by discontinuous SDS-PAGE with a $10 \%$ resolving gel and electro-transferred using a Bio-Rad Mini-Trans Blot electrophoretic transfer cell (Bio-Rad Laboratories, Inc.) according to the manufacturer's instructions onto polyvinylidene diflouride membranes (Immobilon ${ }^{\circledR}$; IPVH00010; Merck KGaA). The membranes were incubated with blocking buffer [5\% (w/v) bovine serum albumin (BSA) and $0.1 \%(\mathrm{v} / \mathrm{v})$ Tween-20 in TBS (TBST), or 5\% non-fat milk $(\mathrm{w} / \mathrm{v})$ and $0.1 \%(\mathrm{v} / \mathrm{v})$ TBST, for GAPDH] for $1 \mathrm{~h}$ at room temperature, followed by incubation with the following specific antibodies: EGFR rabbit-antibody $(1: 1,000)$, rabbit phosphorylated (p)EGFR Y1068 antibody (ab5644; 1:1,000; Abcam), rabbit pEGFR Y1045 antibody (2237S; 1:1,000; Cell Signaling Technology, Inc.), rabbit pEGFR Y1172 antibody (ab135560; 1:2,000; Abcam) and GAPDH rabbit antibody in blocking buffer and incubated overnight at $4^{\circ} \mathrm{C}$. The membranes were washed extensively with TBST and incubated with horseradish peroxidase-conjugated anti-rabbit immunoglobulin (Ig)G (7074S; 1:2,000; Cell Signaling Technology, Inc.) for $3 \mathrm{~h}$ at room temperature. The membranes were then washed with TBST, prior to being visualised with Thermo Scientific ${ }^{\mathrm{TM}}$ Pierce $^{\mathrm{TM}}$ ECL-plus reagent (80196; Thermo Fisher Scientific, Inc.) according to the manufacturer's instructions, using CL-Xposure ${ }^{\mathrm{TM}} \mathrm{X}$-ray film (34088; Thermo Fisher Scientific, Inc.). ImageJ software v1.52 (National Institutes of Health, Bethesda, MD, USA) was employed for densitometric analysis of western blots. Band intensities were quantified ( $n=3$ experiments) and pEGFR or EGFR levels were calculated relative to GAPDH, the loading control. pEGFR levels were also calculated relative to total EGFR. Data points represent mean \pm standard error of the mean. Statistical analysis was performed using one-way analysis of variance followed by Dunnett's post hoc test.

Microscopy. For EGF clustering, SW480 cells were seeded onto glass coverslips at $\sim 0.3 \times 10^{6}$ cells/well and cultured in Leibovitz L-15 medium containing $10 \%$ (v/v) FBS supplemented with antibiotics to $70-80 \%$ confluence in 6 -well tissue culture plates. Cells were then cultured in serum-free L-15 medium with antibiotics for $48 \mathrm{~h}$. Monolayers were cooled to $4^{\circ} \mathrm{C}$ and incubated for $60 \mathrm{~min}$ in the presence of $100-500 \mathrm{ng} / \mathrm{ml}$ Alexa Fluor 555-EGF at $4^{\circ} \mathrm{C}$. For experiments testing compounds, serum-starved cells were pre-incubated at $37^{\circ} \mathrm{C}$ for $30 \mathrm{~min}$ in the absence or presence of compounds (Table I), followed by $15 \mathrm{~min}$ at $4^{\circ} \mathrm{C}$ prior to the addition of an equal volume of cold $\left(4^{\circ} \mathrm{C}\right)$ serum-free culture medium containing $200 \mathrm{ng} / \mathrm{ml}$ Alexa Fluor 555-EGF and incubation for $60 \mathrm{~min}$ allowing EGF binding. Prolonged incubation previously facilitated recruitment of ligand-receptor complexes into clathrin-coated pits $(41,42)$. Cells were warmed to $37^{\circ} \mathrm{C}$ over $25-30 \mathrm{~min}$ to stimulate EGF and EGFR internalisation, washed with PBS, fixed for $5 \mathrm{~min}$ with cold acetone/methanol $\left(-20^{\circ} \mathrm{C} ; 1: 1, \mathrm{v} / \mathrm{v}\right)$ and the coverslip was then placed onto a drop of VectaShield mounting medium prior to immediate epifluorescence or confocal microscopy at x400 magnification. For preliminary experiments, cells were incubated at $37^{\circ} \mathrm{C}$ with $1 \mathrm{mM}$ aspirin, Di-A, F-DiA or with $0.5 \mathrm{mM}$ PN529 (Table I) for $30 \mathrm{~min}$ in serum-free medium or with an equivalent final concentration of DMSO as described above, prior to the addition of fluorescently-labelled EGF. Epifluorescence microscopy was carried out using an Olympus BX61 microscope with TXRED filter set (excitation, 580-590 nm; emission, 615-630 nm; Olympus Corporation, Tokyo, Japan). For confocal microscopy a Zeiss LSM510 Meta or a Zeiss LSM880 with Airyscan (Zeiss $\mathrm{GmbH}$, Jena, Germany), equipped with an argon excitation laser (458, 488 and $514 \mathrm{~nm}$ ), using a 63 x 1.4 NA oil immersion objective. DAPI (Dako; Agilent Technologies, Inc., Santa Clara, CA, USA) was used as a nuclear counter stain (room temperature, $\geq 30 \mathrm{~min}$ ) in certain experiments

For EGFR clustering, SW480 cells were cultured on glass coverslips in 6-well tissue culture plates to $70 \%$ confluence and serum-starved for $48 \mathrm{~h}$. For experiments testing compounds, cells were pre-incubated at $37^{\circ} \mathrm{C}$ for $30 \mathrm{~min}$ in the absence or presence of the drug, followed by $15 \mathrm{~min}$ at $4^{\circ} \mathrm{C}$ prior to 
the addition of equivalent volume of cold $\left(4^{\circ} \mathrm{C}\right)$ serum-free culture medium containing $250 \mathrm{ng} / \mathrm{ml}$ (stock) recombinant (r)EGF (cat. no. E9644; Sigma-Aldrich; Merck KGaA, Darmstadt, Germany) to achieve a final concentration of 125 $\mathrm{ng} / \mathrm{ml} \mathrm{rEGF}$. The cells were then incubated for $60 \mathrm{~min}$ at $4^{\circ} \mathrm{C}$ to allow EGF binding. The cells were warmed to $37^{\circ} \mathrm{C}$ over 25 min to stimulate EGF clustering and EGFR internalisation, washed with $\mathrm{PBS}$, fixed for $5 \mathrm{~min}$ with acetone/methanol $\left(-20^{\circ} \mathrm{C} ; 1: 1, \mathrm{v} / \mathrm{v}\right)$ and incubated with blocking buffer for $60 \mathrm{~min}$ at room temperature. The cells were then incubated with anti-EGFR (D38B1) $\mathrm{XP}^{\circledR}$ rabbit antibodies (Alexa Fluor 488-conjugate; $1: 100$ ) for $60 \mathrm{~min}$ in blocking buffer at $37^{\circ} \mathrm{C}$, washed with PBST $(0.02 \%)$ and the coverslips were placed onto a drop of Prolong Gold antifade reagent with DAPI mounting medium (cat no. P36935; Invitrogen; Thermo Fisher Scientific, Inc.) prior to fluorescence microscopy (x400). Aspirin, DiA, F-DiA and PN529 were added at a final concentration of 0.5 or $1 \mathrm{mM}$ to independent wells in 6-well plates. The controls without aspirin analogue were fixed following EGF binding for $60 \mathrm{~min}$ (no EGF internalisation) or following warming of the cells for $25 \mathrm{~min}$ at $37^{\circ} \mathrm{C}$ (with EGF internalisation).

For EEA1 staining, SW480 cells were seeded onto glass coverslips at $\sim 0.3 \times 10^{6}$ cells/well and cultured to $\sim 70 \%$ confluence in 6-well tissue culture plates and serum-starved for $48 \mathrm{~h}$. For experiments for preliminary testing of compounds, serum-starved cells were preincubated at $37^{\circ} \mathrm{C}$ for $30 \mathrm{~min}$ in the absence or presence of compounds, followed by $15 \mathrm{~min}$ at $4{ }^{\circ} \mathrm{C}$, prior to addition of the equivalent volume of cold serum-free culture medium containing $200 \mathrm{ng} / \mathrm{ml}$ Alexa Fluor $555-E G F$ (final concentration of $100 \mathrm{ng} / \mathrm{ml}$ ) and incubation on ice for $1 \mathrm{~h}$ to allow EGF binding. In later experiments, the concentration was reduced to $20 \mathrm{ng} / \mathrm{ml}$. Cells were warmed to $37^{\circ} \mathrm{C}$ over $30 \mathrm{~min}$ to stimulate EGF internalisation, washed with cold $\left(4^{\circ} \mathrm{C}\right) \mathrm{PBS}$ thrice and fixed for 5 min with acetone/methanol $(1: 1, \mathrm{v} / \mathrm{v})$ at $-20^{\circ} \mathrm{C}$ on ice. Cells were washed with cold PBS and blocked in blocking buffer [3\% (w/v) BSA and $0.2 \%(\mathrm{v} / \mathrm{v})$ Tween-20 in PBS] for $2 \mathrm{~h}$ at room temperature in the dark. Anti-EEA1 antibody was added to cells at 1:1,000 dilution and incubated at $4^{\circ} \mathrm{C}$ overnight with gentle rocking. Cells were washed with cold $\left(4^{\circ} \mathrm{C}\right)$ blocking buffer $[3 \%(w / v)$ BSA and $0.2 \%(\mathrm{v} / \mathrm{v})$ Tween-20 in PBS] thrice and incubated with goat anti-mouse IgG H\&L-fluorescein isothiocyanate (ab6785; 1:1,000; Abcam) secondary antibody for $2 \mathrm{~h}$ at room temperature. Cells were then washed with cold blocking buffer [3\% (w/v) BSA and $0.2 \%(\mathrm{v} / \mathrm{v})$ Tween-20 in PBS] thrice and with cold PBS prior to placing coverslips onto a drop of VectaShield mounting medium. Microscopy was performed using a Zeiss LSM 880 confocal microscope, equipped with 405 and $561 \mathrm{~nm}$ excitation lasers using a 40x/1.30 NA oil immersion DIC M27 objective.

Image acquisition and processing. Images were acquired and processed with Olympus compatible software (IPLab Imaging software v3.1; BD Biosciences, San Jose, CA, USA) or Zeiss software [ZEN 2.3 lite (blue edition), or Zeiss LSM Image Examiner Version 3.2.0.115; both Carl Zeiss AG, Oberkochen, Germany] and minor brightness, contrast and tonal alterations were performed with Adobe Photoshop CS6 (Adobe Systems, Inc., San Jose, CA, USA) or GIMP (https://www.gimp.org/).
For semi-quantitative determination of EGF internalisation, the goal of development of the proximity and density quotient (PDQ) was to establish a metric that provides a quantitative estimate of the degree of localisation of labelled EGF to the cell nucleus. A way of doing this would be to determine the mean density value of the protein molecules and another density value in the vicinity of the nuclei and calculate a quotient. A visual inspection of the data to be analysed demonstrated an effect, whereby the clustering around one nucleus would have a major effect on the overall density around a neighbouring nucleus. For this reason, it is necessary to count only those molecules, which are unambiguously within the influence of the nucleus being studied. This is achieved by defining the region of interest for each nucleus. Each molecule is allocated to a region defined by the closest nucleus. Within this region, the evenness of the distribution of proteins is measured by counting them within an area around each nucleus. The outer area is a torus extending from the full radius of the measurement area to half of that radius. The inner area is a disc within the torus. The PDQ for an individual nucleus is the ratio of the number of molecules counted in the outer area to those counted in the overall area. A larger PDQ indicates reduced clustering of molecules around the nucleus. Formally, the calculation of the PDQ is performed as follows: A set of nuclei, N, and a set of protein molecules, $M$ were defined. A set of protein molecules associated with each nucleus, n, was identified as:

$$
M_{n}=\left\{m \in M: n \in N \wedge\left(\forall n_{-} \in(N-\{n\}): \operatorname{dist}\left(m, n_{-}\right)>\operatorname{dist}(m, n)\right)\right\},
$$

with $\operatorname{dist}(\mathrm{m}, \mathrm{n})$ as the Cartesian distance of the molecule $\mathrm{m}$ from the centroid of the nucleus $n$.

Then, sets of molecules proximate to each nucleus were identified as:

$$
\begin{gathered}
P_{n}=\left\{p \in M_{n}: \operatorname{dist}(p, n)<2 k \operatorname{rad}(n)\right\} \\
Q_{n}=\left\{p \in M_{n}: \operatorname{dist}(p, n)<k \operatorname{rad}\right\},
\end{gathered}
$$

with $\operatorname{rad}(n)$ as the mean radius of the nucleus and $k$ as an empirical constant, selected to maximise discrimination of PDQ in the control sets.

The PDQ for a molecule is calculated as the ratio of the difference of the cardinalities of $P_{n}$ and $Q_{n}$ and the cardinality of $P_{n}$.

$$
P D Q_{n}=\frac{\left|P_{n}\right|-\left|Q_{n}\right|}{\left|P_{n}\right|}
$$

The tools used to calculate the PDQ were CellProfiler (43) and the Python programming language (https://www.python. org/). CellProfiler was used to identify, count and locate the two objects of interest, nuclei and protein molecules. The staining of the slides provided a clear contrast between the red-rendered proteins and the blue-rendered nuclei, thus the first operation was to split the image by colour channel. The nuclei required processing in order to be reliably and unambiguously identified, which included removal of objects $<50$ pixels across, smoothing and thresholding. Without the latter steps, the segmentation algorithm would split single nuclei into several objects. Identification of protein molecules required suppression of objects $<3$ pixels. It is to be expected that different slide processing would require tuning of the image processing in order to reliably identify the two types of objects. CellProfiler provided tables of data listing each of the 
objects identified, its position and size. A Python program was written, which implemented the algorithm described above. It was used to further process these data. The value of $\mathrm{k}$, which provided best differentiation between the positive and negative control sets, was 4.

Compound synthesis. Full details of all the compounds referred to in the present study are provided in Table I. Aspirin analogues were, wherever possible, synthesised as previously described (26,27). Meta-apirin (PN548) and para-aspirin (PN549) were made by a standard aspirin synthesis using 3-hydroxy and 4-hydroxybenzoic acids as starting materials, in lieu of salicylic acid. The three isomeric thioaspirin analogues (PN590, PN591 and PN592, represented as ortho-TASP, meta-TASP and para-TASP respectively) were prepared in good yields $(\sim 70 \%)$ from the corresponding mercaptobenzoic acids, by reaction with acetic anhydride in ice-cold sodium hydroxide solution, as previously described (44). In the present study, sodium hydroxide, rather than the potassium salt, was used without observing any changes. While the previously published method (39) only describes the preparation of the meta- and para-isomers (meta-TASP and para-TASP) it was demonstrated that the method also yields the ortho-isomer (ortho-TASP). The crude products in each case were demonstrated by thin layer chromatography and melting point comparison to be suitable for use without any further purification. Details of the additional compounds synthesised specifically for use in the present study are provided below. All percentage yields were comparable to the published values and within $15 \%$. NMR spectra were recorded on a Jeol ECS-400 instrument.

Meta-aspirin (3-acetoxybenzoic acid): White powder; melting point (mpt), $131-134^{\circ} \mathrm{C}$ (literature, $131-134^{\circ} \mathrm{C}$ ); ${ }^{13} \mathrm{C}-\mathrm{NMR}\left(\mathrm{CDCl}_{3}\right) \delta=171.19,169.32,150.75,130.88,129.68$, 127.72, 127.33, 123.53, 21.14 ppm; Infra Red (IR), 3,400-2,200, $1,758,1,675,1,584 \mathrm{~cm}^{-1}$.

Para-aspirin (4-acetoxybenzoic acid): White powder; mpt, $183-185^{\circ} \mathrm{C}$ (literature, $\left.187^{\circ} \mathrm{C} ; 190-194^{\circ} \mathrm{C}\right) ;{ }^{13} \mathrm{C}-\mathrm{NMR}\left(\mathrm{CDCl}_{3}\right)$ $\delta=171.31,168.96,155.06,131.96,126.88,121.85,21.25$ ppm; IR 3500-2200, 1754, 1677, $1602 \mathrm{~cm}^{-1}$.

Thioaspirin (ortho-TASP): White powder; mpt, $122-125^{\circ} \mathrm{C}$ (literature, $\left.125.5-126^{\circ} \mathrm{C}\right)(45) ;{ }^{13} \mathrm{C}-\mathrm{NMR}\left(\mathrm{CDCl}_{3}\right) \delta=193.27$, $171.48,136.82,132.88,132.66,131.92,129.49,129.40,30.45$ ppm; IR 3,380-1,960, 1,694, 1,676, 1,582, 1,565 $\mathrm{cm}^{-1}$.

Meta-thioaspirin (meta-TASP): White powder; mpt, $153-156^{\circ} \mathrm{C}$ (literature, $\left.152-153^{\circ} \mathrm{C}\right)(44) ;{ }^{13} \mathrm{C}-\mathrm{NMR}\left(\mathrm{CDCl}_{3}\right)$ $\delta=193.29,171.09,139.85,136.16,131.19,130.43,129.46,128.88$, 30.38 ppm; IR 3,380-1,990, 1,685 (overlapping thioester and - $\mathrm{COOH} \mathrm{C}=\mathrm{O}$ spectra), 1,583, 1,573 $\mathrm{cm}^{-1}$.

Para-thioaspirin (para-TASP): White powder; mpt, 200-202 ${ }^{\circ} \mathrm{C}$ (literature, 202.5-203.5 $\left.{ }^{\circ} \mathrm{C}\right)(44) ;{ }^{13} \mathrm{C}-\mathrm{NMR}\left(\mathrm{CDCl}_{3}\right)$ $\delta=171.31,168.96,155.06,131.96,126.88,121.85,21.25$ ppm; IR 3,380-1,950, 1,683 (overlapping thioester and $-\mathrm{COOH} \mathrm{C}=\mathrm{O}$ spectra), 1,592, 1,566 $\mathrm{cm}^{-1}$.

\section{Results and Discussion}

EGF and EGFR internalisation. EGFR is an $\sim 170-\mathrm{kDa}$ transmembrane receptor tyrosine kinase, belonging to the ErbB family of signalling receptors, whose ligands include
EGF and transforming growth factor- $\alpha$, with roles in cellular proliferation, survival and differentiation $(46,47)$. Dysfunction in the EGFR axis as a consequence of receptor overexpression, amplification and/or mutation has been reported in colorectal, breast, brain, lung, pancreatic, oesophageal and head and neck neoplasias (48-52). EGFR and NF- $\mathrm{B}$ signalling are intimately linked $(53,54)$ and it has been reported that the aspirin analogues DiA and F-DiA can perturb NF- $\kappa \mathrm{B}$ activity in SW480 cells and that salicylates can potentially antagonise wound healing. Therefore, the aim of the present study was to investigate the effect of aspirin and aspirin-like molecules $(26,27)$ on EGF endocytosis in the context of a rapid cell biological effect, in contrast to many experiments that examine the consequences of compound exposure of cells and tissues over protracted time frames (days). Compound toxicity was determined by the MTT assay and the $\mathrm{IC}_{50}$ values are presented in Table I. The aspirin analogues synthesised and tested contain modifications to either the number of rings, to the position of the acetyl group and/or have a substituted thiol group. Diflunisal is a difluorophenyl derivative of salicylic acid and is a clinically utilised NSAID with analgesic and anti-inflammatory properties.

In preliminary experiments to assess compound effects on EGF internalisation, a commercially available fluorescence-labelled, $\mathrm{pH}$-insensitive conjugate of EGF was used. Serum-starved SW480 cells were incubated with aspirin analogues, cooled on ice to inhibit endocytosis and allowed EGF-conjugate binding for $1 \mathrm{~h}$ prior to tracking the internalised EGF by confocal and DIC microscopy (Fig. 1) and immunofluorescence analysis (data not shown). In SW480 cells incubated in the absence of compounds, following $\sim 25 \mathrm{~min}$ of warming to $37^{\circ} \mathrm{C}$, EGF was observed to internalise with clustering often in a perinuclear location, with the nucleus clearly visible (Fig. 1). However, in the presence of aspirin, DiA and F-DiA, internalisation and perinuclear clustering was inhibited. In cells incubated with DiA, substantial clustering was noted to persist at or near the membrane, whereas with F-DiA, staining was notably diffused. These data suggested that compounds based on salicylate may perturb EGF internalisation and affect signalling, given that correctly regulated EGF internalisation and signalling via endosomes are associated $(55,56)$. To examine this phenomenon further, serum-starved SW480 cells were incubated with compounds prior to stimulation with recombinant human EGF $(125 \mathrm{ng} / \mathrm{ml})$ and EGFR localisation was probed by immunofluorescence analysis using a commercially available anti-EGFR monoclonal antibody. Peripheral, presumably membranous staining, was clearly visible in the absence of warming (Fig. 2A), indicating that the EGFR is robustly expressed in the SW480 cell line, as previously reported (29). Internalised punctate staining of the EGFR demonstrated close proximity to the nucleus when the cells were warmed to $37^{\circ} \mathrm{C}$ within $25 \mathrm{~min}$ (Fig. 2B). In the presence of aspirin, DiA and F-DiA, during the internalisation of the receptor, staining was substantially more diffuse with all compounds (Fig. 2C-E). Furthermore, when cells were incubated with PN529 (isopropyl $m$-bromobenzoylsalicylate), a toxic brominated salicylate (27), EGFR staining was markedly dissimilar compared with the control cells (Fig. 2B and F). Clustering of labelled EGFR to perinuclear locations was consistently observed following a 25-min incubation in the 

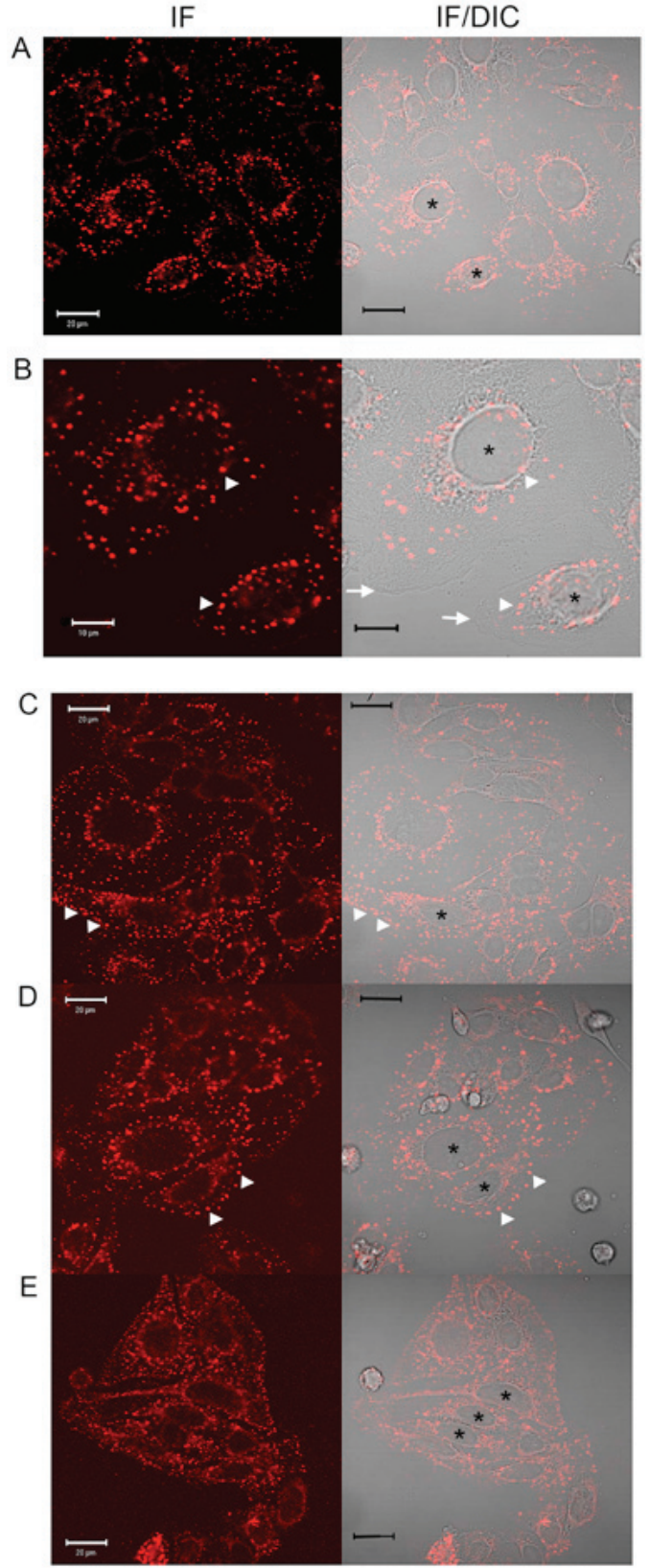

Figure 1. Effects of aspirin, DiA and F-DiA on EGF internalisation in SW480 cells. Internalisation of Alexa Fluor 555-EGF following 25 min at $37^{\circ} \mathrm{C}$ examined by (A and B) confocal microscopy (left panel) and highlighting the clustering, with merged DIC image (right panel). Internalisation of Alexa Fluor 555-EGF following $25 \mathrm{~min}$ at $37^{\circ} \mathrm{C}$ following preincubation for 30 min at $4^{\circ} \mathrm{C}$ with (C) $1 \mathrm{mM}$ aspirin, (D) $1 \mathrm{mM}$ DiA or (E) $1 \mathrm{mM}$ F-DiA and stimulation by warming of the cells to $37^{\circ} \mathrm{C}$. "Indicates nuclei for the interpretation of DIC microscopy, arrowheads indicate tagged EGF and arrows highlight the plasma membrane. DiA, diaspirin; F-DiA, fumaryldiaspirin; EGF, epidermal growth factor; DIC, differential interference contrast; IF, immunofluorescence.

absence of compounds in cells warmed to $37^{\circ} \mathrm{C}$. However, in the presence of aspirin and, more prominently, in the presence of DiA, F-DiA and isopropyl (m-bromobenzoylsalicylate), discrete perinuclear clustering was substantially inhibited. These data suggest that aspirin and analogues rapidly perturb EGFR internalisation, and this observation may not solely be caused by a reduction in binding, as staining observed with fluorescence-tagged EGF was robust even following aspirin, F-DiA, PN524 or ortho-TASP treatment (data not

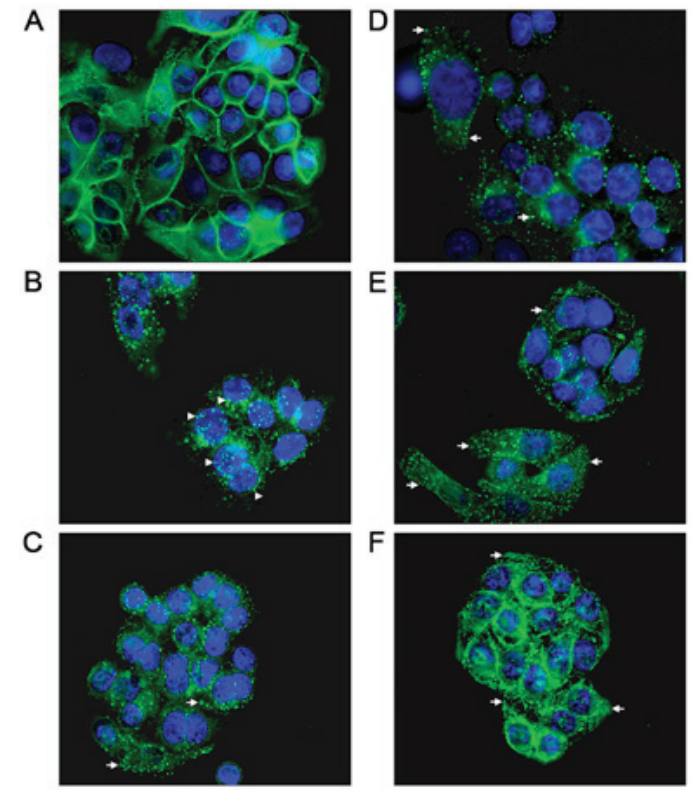

Figure 2.Immunofluorescence analysis of the effects of aspirin and aspirin-like analogues on EGFR internalisation in SW480 cells. Serum-starved SW480 cells were incubated with aspirin or diaspirin compounds and human EGF. The samples were warmed to stimulate EGF internalisation and stained using the EGFR XP ${ }^{\circledR}$ rabbit antibody (Alexa Fluor 488-conjugate; green). (A) Vehicle control at $4{ }^{\circ} \mathrm{C}$ with cells incubated with $125 \mathrm{ng} / \mathrm{ml} \mathrm{EGF}$. Cells stimulated with $125 \mathrm{ng} / \mathrm{ml} \mathrm{EGF}$ and warmed to $37^{\circ} \mathrm{C}$ over $25 \mathrm{~min}$ with (B) no preincubation, (C) $1 \mathrm{mM}$ aspirin, (D) $1 \mathrm{mM}$ DiA, (E) $1 \mathrm{mM}$ F-DiA and (F) $1 \mathrm{mM}$ isopropyl-bromobenzoylsalicylate preincubation. Cells were fixed and observed by epifluorescence microscopy. Blue highlights DAPI-stained DNA. Pronounced clustering of the EGFR to a perinuclear location occurs upon warming cells (arrowheads). In the presence of compounds, the clustering is less perinuclear and/or more diffuse (arrows). Magnification, x600. EGFR, epidermal growth factor receptor; EGF, epidermal growth factor; DiA, diaspirin; F-DiA, fumaryldiaspirin.

shown). Whilst the concentration of the tested compounds in the experiments may appear high in comparison with other chemotherapeutic agents, a range of 1-5 mM or above is not uncommon in in vitro experiments investigating the molecular action of aspirin or salicylate $(21,22,57,58)$, with levels of $0.5-2 \mathrm{mM}$ also reported as being physiologically or therapeutically relevant by a number of investigators (59-62).

EGF endocytosis in the presence of salicylate derivatives. Ligand binding leads to conformational changes in EGFR and EGFR dimerization (63-65), autophosphorylation of the cytoplasmic tyrosine kinase domain with subsequent downstream signalling through the RAS [mitogen-activated protein kinase (MAPK)], phosphoinositide 3-kinase (AKT) and janus kinase (JAK; signal transducer and activator of transcription factor 3 ) pathways $(53,66,67)$. Concomitantly, the ligand receptor complex is internalised via clathrin-dependent and -independent routes, depending on EGF levels, with clathrin-mediated endocytosis prolonging signalling (68-70). Signalling from endosomes with activated EGFR may persist $(71,72)$ and the activated EGFR may ultimately be recycled or degraded (73). Indeed, internalised endosomes may be considered as signalling platforms (56). An early destination for internalisation is the EEA1-positive endosomal compartment depending on whether or not a clathrin-mediated endocytosis occurred (74). Clustering of late endosomes is 
at a perinuclear location and mislocalised endosomes can compromise signalling quality (55). In addition, it has been suggested that EGFR can translocate to the nucleus and signal therein (75-78).

EEA1 is a Rab5 effector, intimately involved in tethering, docking and fusion of early endosomes (79) and mediating crosstalk between signalling pathways (80). It was therefore examined whether spatial and temporal regulation of the internalisation of EGF was perturbed by examining the colocalisation of Alexa Fluor 555-labelled EGF (100 ng/ml) and EEA1 following a chase in the absence and presence of aspirin and aspirin analogues. This was performed while additionally controlling $\mathrm{pH}$ alterations with HEPES (10 mM at pH 8; Fig. 3) or phosphate buffers (data not shown) to minimise acidification caused by the addition of the aspirin derivatives. Buffering did not appear to attenuate the effects exhibited by aspirin and aspirin analogues. Peripheral EGF staining, interpreted as membrane-localised, was apparent without a chase, whereas EGF internalisation to a perinuclear location occurred in the absence of compounds upon warming to $37^{\circ} \mathrm{C}$ in the vehicle control group (Fig. 3). In the presence of compound at $0.5 \mathrm{mM}$, a concentration used to reduce any non-specific effects caused by acidification, and under buffered conditions, aspirin or aspirin analogues rapidly perturbed EGF internalisation (Fig. 3A). Colocalisation of EEA1 and EGF was consistently enhanced, as evidenced by dual staining, when cells were incubated with F-DiA, suggesting that the pathway of internalisation of EGF in the presence of F-DiA is substantially altered in comparison to aspirin and PN524, a brominated salicylate exhibiting an intermediate toxicity between aspirin and F-DiA (27) to SW480 cells. Furthermore, endosomal EEA1 staining was enhanced, when cells were incubated with F-DiA, based on the intensity of the fluorescence in the perinuclear location.

EGF internalisation (at $100 \mathrm{ng} / \mathrm{ml}$ ) was analysed semi-quantitatively with PDQ measurements of the labelled EGF relative to the nucleus (Fig. 3B) in the presence of $0.5 \mathrm{mM}$ aspirin, PN517 (F-DiA) or diflunisal. A larger PDQ indicated reduced clustering of molecules around the nucleus. Significant perturbation of internalisation was noted with all three compounds. It was previously demonstrated that F-DiA is significantly more effective at inducing apoptosis in CRC cells compared with aspirin, strongly reduces cyclin D1 levels and inhibits NF- $\mathrm{B}$ activity in vitro (27).

Given that endocytosis of the EGFR has been proposed to occur via a number of pathways, depending on the saturability of EGF ligand-induced receptor internalisation $(42,81,82)$, the cells were additionally stimulated with relatively low EGF concentrations (20 ng/ml) under buffered conditions (HEPES). These experiments were performed to elucidate the influence of the tested compounds on EGF and EGFR internalisation and further utilised EEA1 staining (Fig. 4). Similar to experiments using $100 \mathrm{ng} / \mathrm{ml} \mathrm{EGF,} \mathrm{aspirin} \mathrm{and} \mathrm{F-DiA} \mathrm{perturbed} \mathrm{EGF}$ internalisation compared with the vehicle control and colocalisation of EGF with EEA1 was markedly enhanced as a consequence of a brief incubation with $0.5 \mathrm{mM}$ F-DiA.

The universality of the phenomenon of perturbing EGF internalisation at $20 \mathrm{ng} / \mathrm{ml}$ was examined, with a wider range of salicylate derivatives (at $0.5 \mathrm{mM}$ ), including diflunisal. Dysregulation in EGF internalisation was noted with all compounds under HEPES-buffered conditions (Fig. 5)
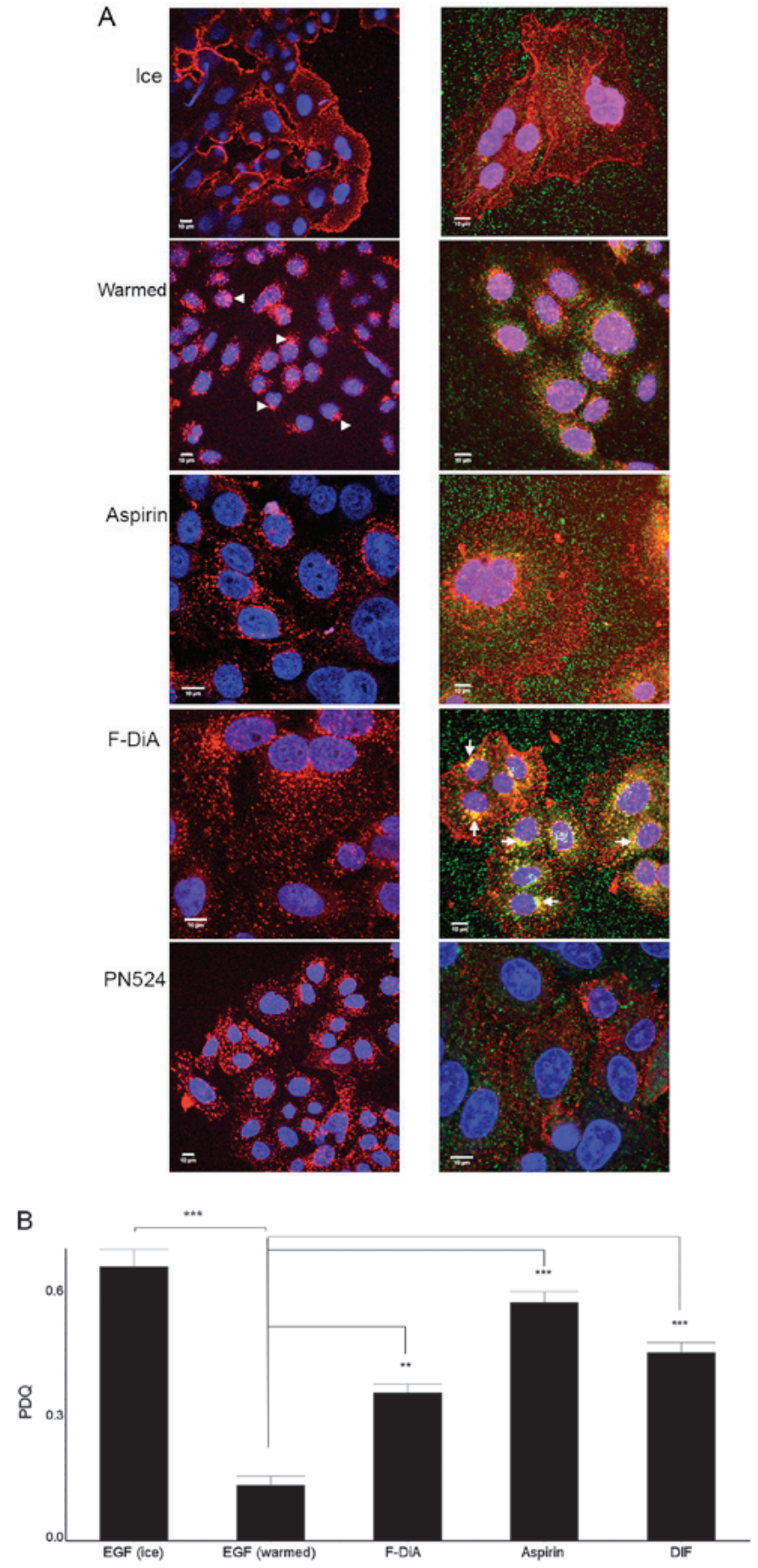

Figure 3. (A) Effect of aspirin and aspirin analogues under HEPES-buffered conditions on EGF internalisation $(100 \mathrm{ng} / \mathrm{ml})$ and EGF colocalisation with EEA1. Confocal analysis of SW480 colorectal cancer cells incubated with Alexa Fluor 555-EGF and preincubated in the absence or presence of $0.5 \mathrm{mM}$ compound. Analysis was performed in the absence of compound with no warming and no EGF internalisation, and for cells stimulated with warming $\left(37^{\circ} \mathrm{C}\right)$ with and without indicated compounds. EGF fluorescence only (left panel). Merged image for EGF and stained for EEA1 (right panel). Images were acquired at $405 \mathrm{~nm}$ for DAPI nuclear stain (blue), $561 \mathrm{~nm}$ for Alexa Fluor 555-EGF (red) and $488 \mathrm{~nm}$ for fluorescein isothiocyanate for EEA1 (green). Internalisation of EGF to a perinuclear location was noted upon warming to $37^{\circ} \mathrm{C}$ (arrowheads). In the presence of compounds, internalisation was perturbed, and with F-DiA colocalisation of EGF with EEA1 was observed (arrows). (B) Nuclear PDQ for labelled EGF was determined by image analysis of three repeated experiments; data points represent mean \pm standard error of the mean. Statistical analysis comparing the PDQ of unstimulated and warmed cells without and with compounds was performed using Kruskal-Wallis with Dunn's post-hoc test. ${ }^{* *} \mathrm{P}<0.01$ and ${ }^{* * *} \mathrm{P}<0.001$. EGF, epidermal growth factor; EEA1, early endosome antigen 1; F-DiA, fumaryldiaspirin; PDQ, proximity and density quotient; DIF, diflunisal. 

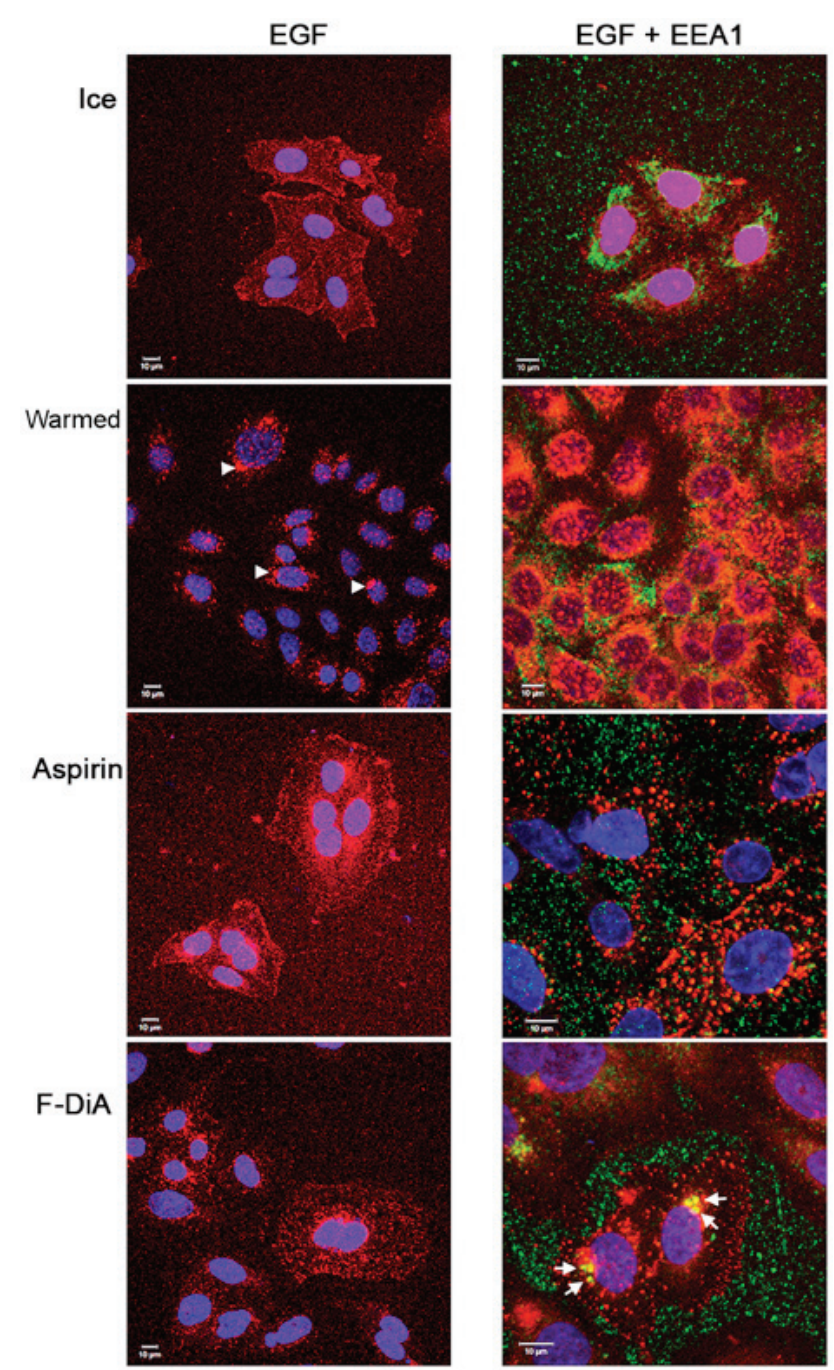

Figure 4. Effect of aspirin analogues in HEPES-buffered conditions on EGF $(20 \mathrm{ng} / \mathrm{ml})$ internalisation and EGF colocalisation with EEA1. Confocal analysis of SW480 colorectal cancer cells incubated with Alexa Fluor 555-EGF and preincubated in the absence or presence of $0.5 \mathrm{mM}$ compound. Analysis was performed in the absence of compound with no warming and no EGF internalisation and for cells stimulated with warming $\left(37^{\circ} \mathrm{C}\right)$ with and without indicated compounds. EGF fluorescence only (left panel). Merged image for EGF and stained for EEA1 (right panel). Images were acquired at $405 \mathrm{~nm}$ for DAPI nucleic stain (blue), $561 \mathrm{~nm}$ for Alexa Fluor 555-EGF (red) and $488 \mathrm{~nm}$ for fluorescein isothiocyanate for EEA1 (green). Representative images were taken at $x 40$ magnification in oil/1.30 NA. oil immersion objective lens $(n=3)$. Internalisation of EGF to a perinuclear location was noted upon warming (arrowheads). In the presence of compounds, internalisation was perturbed and with F-DiA colocalisation of EGF with EEA1 was also observed (arrows). EGF, epidermal growth factor; EEA1, early endosome antigen 1; F-DiA, fumaryldiaspirin.

compared with the vehicle control, including salicylic acid per se (Fig. 5A), aspirins with modifications to the position of the acetyl group (Fig. 5B and F) and/or compounds with an additional thiol group (Fig. 5D, $\mathrm{G}$ and $\mathrm{H}$ ). When internalisation occurred in the presence of compound, it was often more diffuse than normal and the outline of the cell membrane was visible in some instances, a phenomenon particularly pronounced when the cells were incubated with diflunisal (Fig. 5E). Images were analysed and the PDQ of the labelled EGF relative to the nucleus was determined (Fig. 5I). In summary the data strongly suggested that salicylates and derivatives, at modest concentrations, rapidly altered EGF internalisation

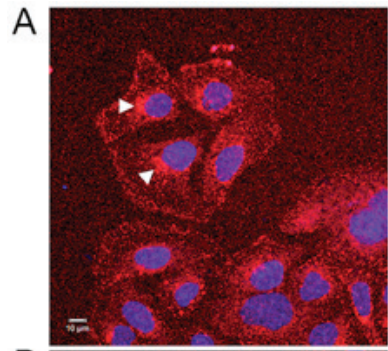

$\mathrm{B}$
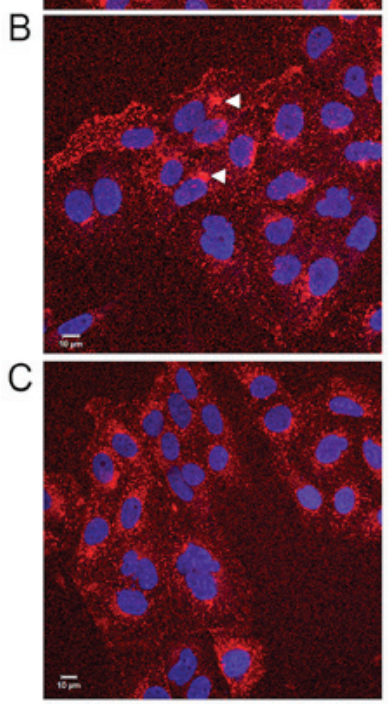

D
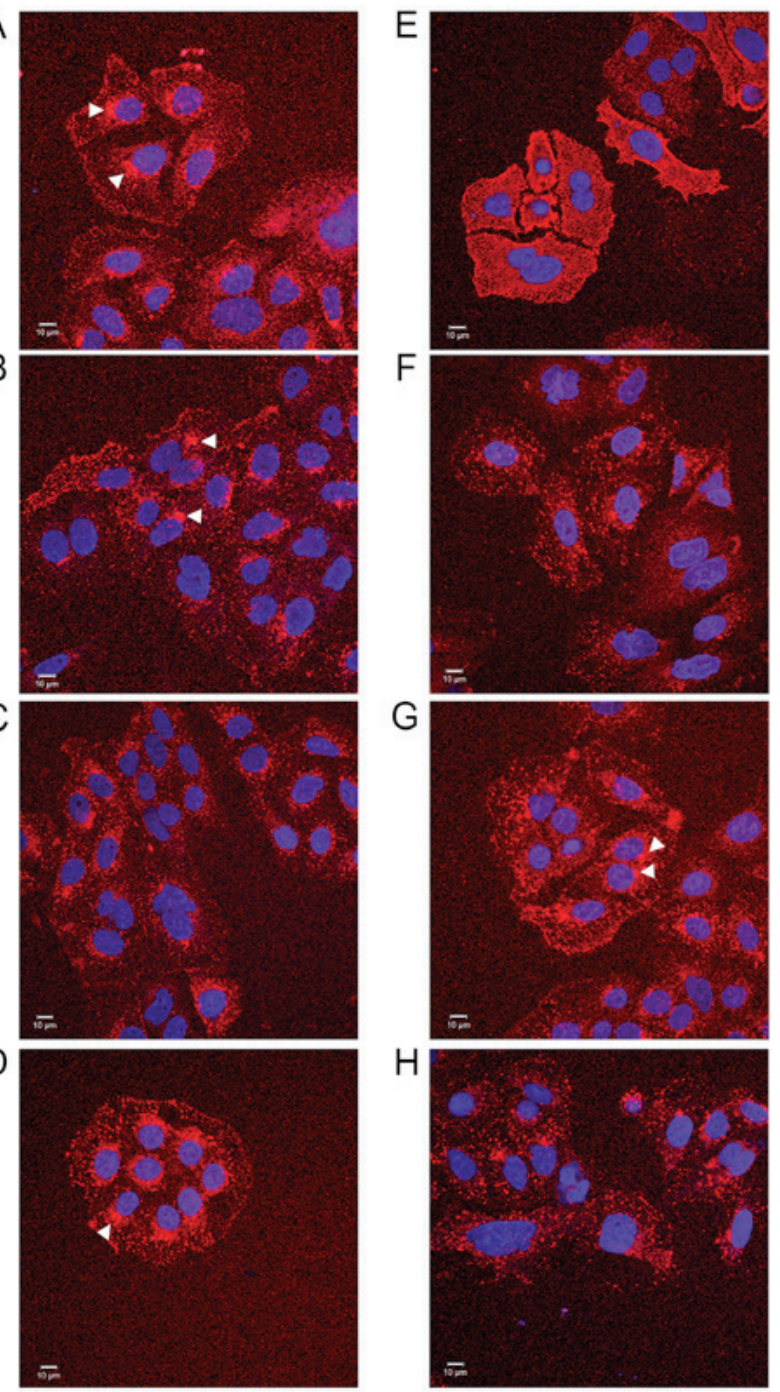

$\mathrm{F}$

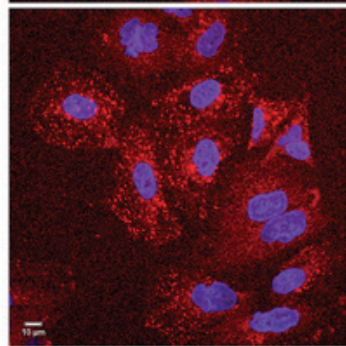

G
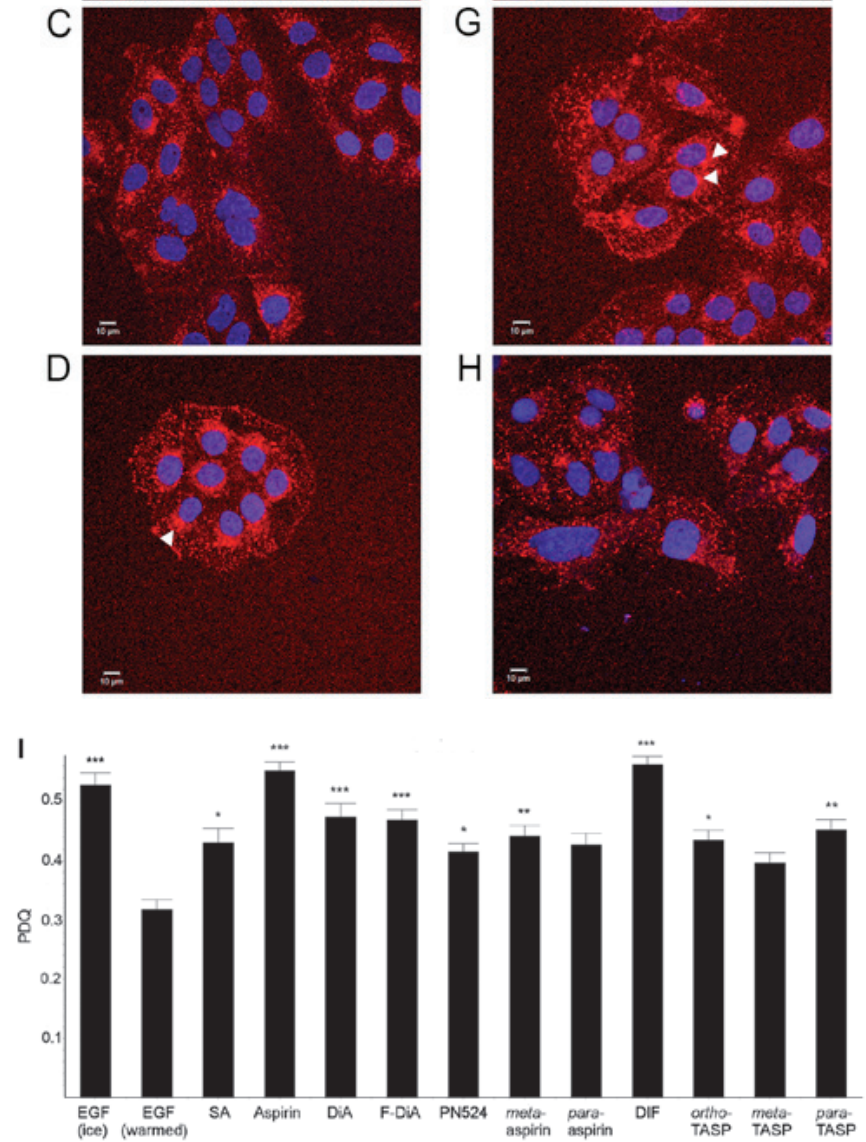

Figure 5. Effect of salicylates and aspirin analogues on EGF internalisation $(20 \mathrm{ng} / \mathrm{ml})$. Confocal analysis of SW480 colorectal cancer cells incubated with Alexa Fluor 555-EGF and preincubated in the absence/ presence of $0.5 \mathrm{mM}$ of the following compound under HEPES-buffered conditions: (A) SA, (B) meta-aspirin, (C) DiA, (D) meta-TASP, (E) DIF, (F) para-aspirin, (G) ortho-TASP and (H) para-TASP. Images were acquired at $405 \mathrm{~nm}$ for DAPI nucleic stain (blue) and $561 \mathrm{~nm}$ for Alexa Fluor-EGF (red). Representative images were taken at $\mathrm{x} 40$ magnification, with an oil/1.30 NA oil immersion objective $(n=3)$. Limited clustering of EGF to a perinuclear location occurred upon warming cells (arrowheads), but was absent with diflunisal. (I) Nuclear PDQ of labelled EGF was determined by image analysis of three repeated experiments; data points represent mean \pm standard error of the mean. Statistical analysis comparing the PDQ of unstimulated and warmed cells with and without stated compounds was performed using Kruskal-Wallis with Dunn's post-hoc test. ${ }^{*} \mathrm{P}<0.05,{ }^{* *} \mathrm{P}<0.01$ and ${ }^{* * * *} \mathrm{P}<0.001$ vs. EGF (warmed). EGF, epidermal growth factor; PDQ, proximity and density quotient. SA, salicylic acid; DiA, diaspirin; DIF, diflunisal; ortho-TASP, ortho-thioaspirin; meta-TASP, meta-thioaspirin; para-TASP, para-thioaspirin. 


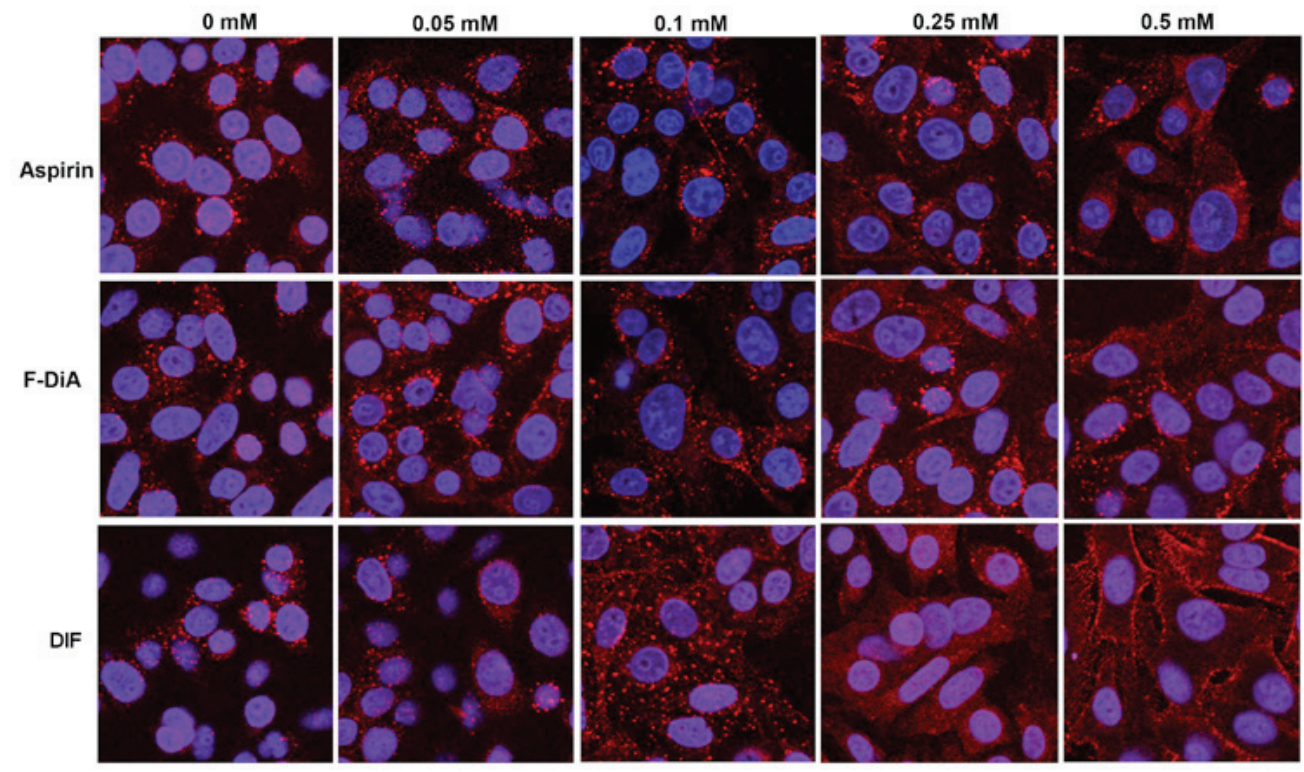

Figure 6. Effect of selected aspirin analogues on EGF $(100 \mathrm{ng} / \mathrm{ml})$ internalisation in the SW480 cell line at concentrations <0.5 mM. Confocal analysis of SW480 colorectal cancer cells incubated with Alexa Fluor 555-EGF and preincubated in the absence/presence of stated compound and vehicle control (0 mM) under HEPES-buffered conditions. Images were acquired at $405 \mathrm{~nm}$ for DAPI nucleic stain (blue) and $561 \mathrm{~nm}$ for Alexa Fluor-EGF (red). Representative images were captured at x400 magnification $(n=3)$. EGF, epidermal growth factor; F-DiA, fumaryldiaspirin; DIF, diflunisal.

and endocytosis. The titratability of the inhibition of EGF internalisation was tested for dose-dependency in the SW480 cell line qualitatively with aspirin, F-DiA (PN517) and diflunisal (selected because of clinical relevance and cytotoxicity) at concentrations below $0.5 \mathrm{mM}$ (Fig. 6), and although observable with aspirin and F-DiA, was most notably observed with diflunisal, thus arguing against a non-specific phenomenon associated with the experimental design.

Aspirin and aspirin analogue effects on EGFR and EGFR phosphorylation. Non-specific inhibition of kinase activity has been proposed as a mechanism of action for aspirin and sodium salicylate (59). Hence, compound effects on EGFR phosphorylation, focusing on cytoplasmic phosphotyrosine residues in the ligand-induced autophosphorylation domain were examined, including Tyr1045, Tyr1068 and Tyr1173. Phosphorylated Tyr1045 acts a site for c-Cbl interaction that results in receptor ubiquitylation and degradation of EGFR, and Cbl regulates receptor downregulation and signalling (83). Phosphorylation of Tyr1068 enhances binding of the growth factor receptor bound protein 2 (Grb2), which is necessary for entry into coated pits (41) and Ras/MAPK activation $(84,85)$. Phospho-Tyr1173 is involved in binding the tyrosine phosphatase SHP1 and signalling via recruitment of the adaptor proteins SHC and Grb2, resulting in control of the ERK activity (86-88). In the present study, SW480 cells were incubated overnight with the compounds of interest and briefly stimulated with $200 \mathrm{ng} / \mathrm{ml} \mathrm{rEGF} \mathrm{(5} \mathrm{min)} \mathrm{in} \mathrm{serum-free}$ medium. EGFR phosphorylation status was analysed by immunoblotting (Fig. 7A). The data suggested that inhibition of EGFR phosphorylation upon stimulation, by aspirin (ortho and meta) was weak. Tyr1045 and Tyr1173 phosphorylation was more sensitive to the presence of diaspirins, including F-DiA (PN517) and PN524, and thioaspirins, including ortho-TASP, meta-TASP and para-TASP, compared with Tyr1068.
Thioaspirin (ortho-TASP) was the sole compound able to inhibit phosphorylation at all sites tested herein. These findings suggested that aspirin and analogues at the concentration tested $(0.5 \mathrm{mM})$, even when cells are stimulated with high rEGF concentrations (200 ng/ml), did not universally inhibit all autophosphorylation sites, which argues against aspirin or its analogues acting solely as a non-specific kinase inhibitor, as suggested by Frantz et al (59). Due to the sensitivity of Tyr1045 to the compounds and its role in receptor degradation, the compound effects on EGF phosphorylation at this site with a 2-h incubation period were further examined and modest changes were observed by immunoblot analysis (Fig. 7B). As aspirin was reported to normalise EGFR expression (89), the effect of aspirin and its analogues on total EGFR levels in SW480 cells was further investigated following a 24-h incubation (Fig. 7C). SW480 EGFR levels were substantively affected by diflunisal, but weaker changes were observed as a result of incubation with F-DiA (PN517), PN524 and PN529, with little evidence of a significant reduction in EGFR by aspirin or salicylate following a 24-h incubation. pEGFR levels relative to total EGFR at pY1068 and pY1173 sites was totally inhibited by ortho-TASP and significantly reduced at pY1045 and pY1173 phosphorylation sites by meta-TASP, para-TASP, F-DiA, DiA and PN524. The pEGFR level at pY1068, pY1045 and pY1173 was increased by aspirin, meta-aspirin and para-aspirin (Fig. 7D).

Taken together, these data suggested that the EGFR axis was sensitive to aspirin and its derivatives. These compounds may have a rapid and profound impact on EGF endcoytosis and autophosphorylation (particularly ortho-TASP with overnight incubation) and, furthermore, to a limited extent, EGFR expression, with the exception of diflunisal. Diflunisal markedly reduced EGFR expression and perturbed EGF internalisation, an observation that, to the best of our knowledge, has not been previously reported for a prescription 
A

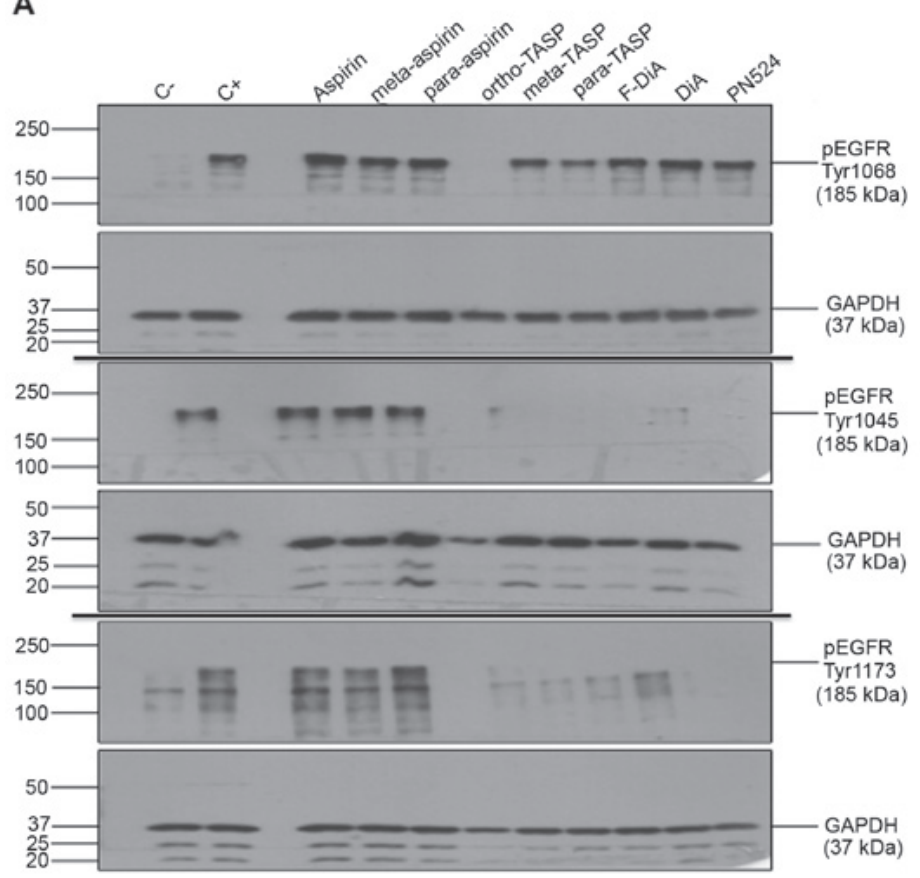

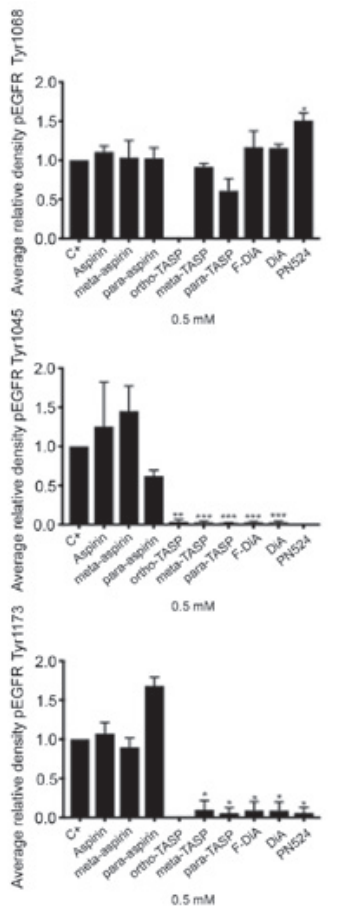

$0.5 \mathrm{~mm}$
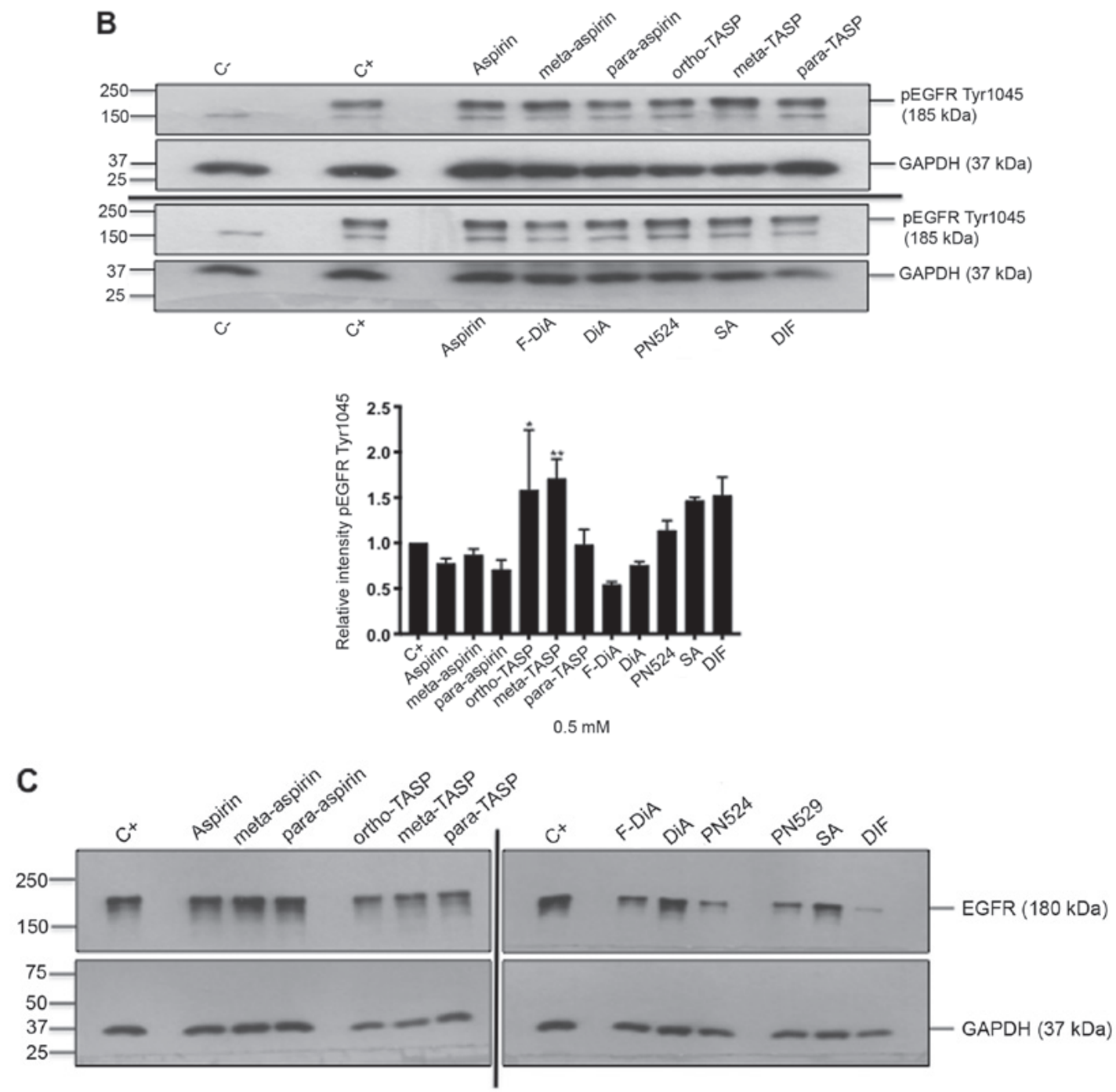

Figure 7. Effect of aspirin and analogues on pEGFR tyrosine kinase phosphorylation sites and EGFR. SW480 colorectal cancer cells were incubated with human rEGF (200 ng/ml) for 5 min following being treated with $0.5 \mathrm{mM}$ compound (HEPES buffered) for (A) $24 \mathrm{~h}$ and probed with anti-human EGFR pY1068, pY1045 and pY1173 antibodies accompanied by corresponding histograms, (B) $2 \mathrm{~h}$ and probed with anti-human EGFR pY1045 and (C) $24 \mathrm{~h}$ and probed with an anti-human EGFR (D38B1) XP rabbit antibody. 

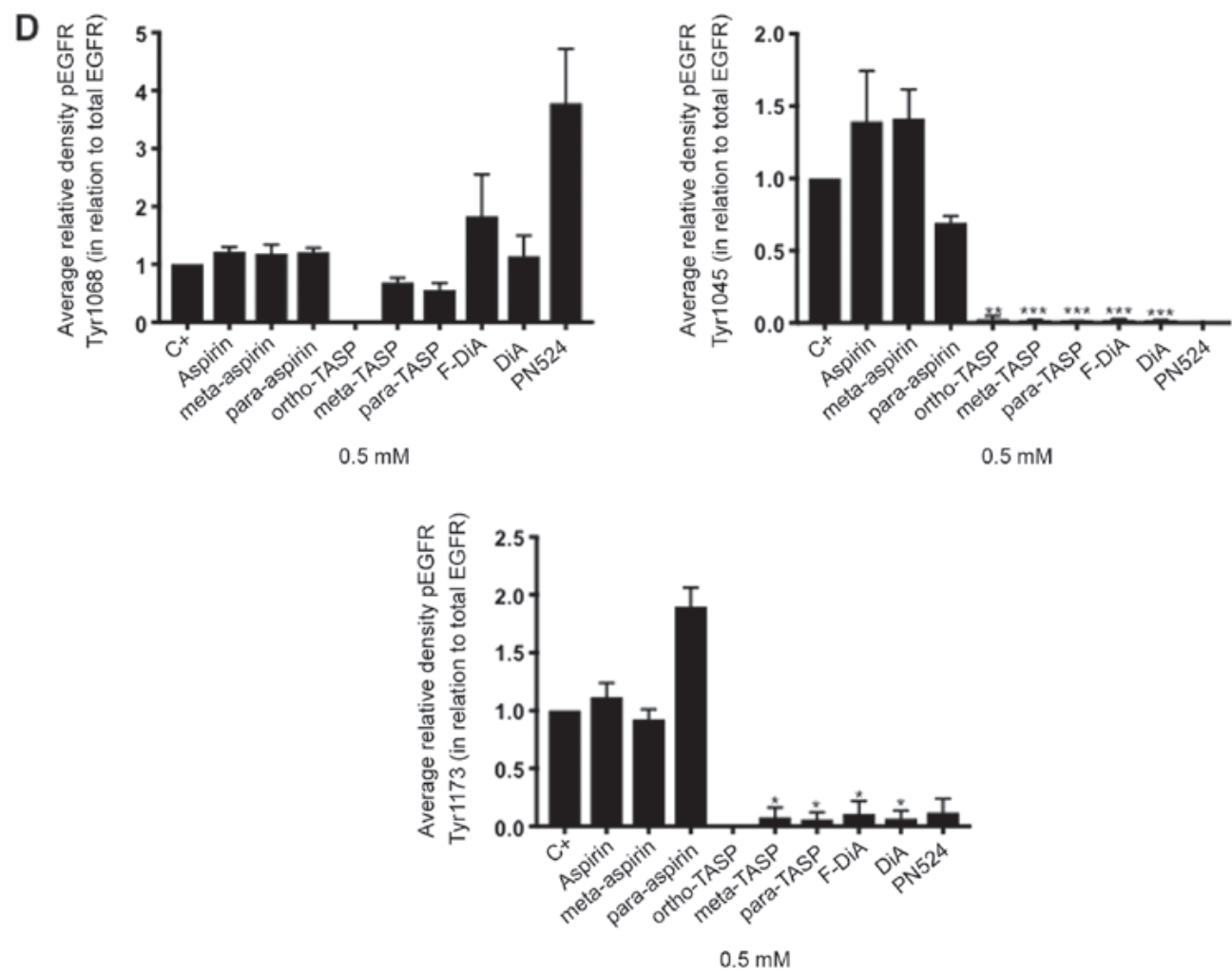

Figure 7. Continued. (D) Quantification of the effect of these compounds on pEGFR tyrosine kinase phosphorylation sites 1,068, 1,045 and 1,173 in relation to total EGFR expression. Cell lysates were analysed by SDS-PAGE and immunoblotting. pEGFR and EGFR bands migrated at $\sim 185$ and $\sim 180 \mathrm{kDa}$, respectively, molecular weight was estimated by interpolation using Precision Plus colour standards. Band intensities were quantified relative to GAPDH. C- represents unstimulated and untreated cells; $\mathrm{C}+$ represents untreated cells stimulated with rEGF for $5 \mathrm{~min}$. Data presented are the mean of three individual experiments \pm standard error of the mean. ${ }^{*} \mathrm{P}<0.05,{ }^{* *} \mathrm{P}<0.01$ and ${ }^{* * * *} \mathrm{P}<0.001$ vs. $\mathrm{C}+$ (one-way analysis of variance followed by Dunnett's test). EGF, epidermal growth factor; EGFR, EGF receptor; pEGFR, phosphorylated EGFR; rEGF, recombinant EGF; Y, tyrosine; SA, salicylic acid; DIF, diflunisal.

drug used in the treatment of osteoarthritis and rheumatoid arthritis. Given that endocytosis of EGF is rapid with migration of the ligand-receptor as a unit to a perinuclear location and then recycled being a canonical pathway for EGF (90) and the role of the proteasome in the processing and degradation of EGFR (91), it would be of interest to determine whether there is any association between diflunisal use and proteasomal degradation of EGFR.

Compound effects on EGF internalisation in Flo-1 and OE33 oesophageal cancer cells. It was further explored whether the phenomenon reported herein was restricted to SW480 cells. To that end and due to evidence that aspirin is chemopreventive in oesophageal cancer $(92,93)$, Alexa Fluor 555-EGF internalisation was examined in the presence of the stated compounds with HEPES buffering in Flo-1 and OE33 oesophageal cancer cells. It was observed that aspirin and F-DiA perturbed EGF internalisation (at $20 \mathrm{ng} / \mathrm{ml}$ ) in the oesophageal cancer cell lines (Fig. 8). EGF internalisation was markedly affected by F-DiA (PN517) in the Flo-1 cells, whereas a modest effect was observed with aspirin.

The present study details a rapid and hitherto unreported effect of aspirin and analogues, which are likely to yield salicylates upon metabolism within cells and tissues, on EGF endocytosis. The study has relevance to wound healing, cellular proliferation and chemoprevention. It addressed the analyses at physiologically achievable levels $(\leq 1 \mathrm{mM})$ of aspirin $(60,61)$ and analogues, and examined EGF internalisation and
EGFR phosphorylation with what is considered to be an experimentally legitimate concentration of EGF $(20 \mathrm{ng} / \mathrm{ml})$ under buffered conditions, as acidification of the cytosol may inhibit endocytosis.

Given the number of compounds tested and for the purposes of clarity the effect of compounds on EGF at unitary values of either 0.5 or $1 \mathrm{mM}$ was investigated. It is recognised that these values are in certain cases $>\mathrm{IC}_{50}$ values for SW480 cells reported herein but with the exception of diflunisal the fold-differences are relatively modest; however, plasma concentrations of diflunisal range from 150-350 $\mu \mathrm{M}$ (22). Most significantly, the concentrations employed for salicylate and aspirin tested were markedly $<\mathrm{IC}_{50}$ values and within a range $(0.5-2 \mathrm{mM})$ that has been reported to be physiologically relevant.

Although a substantial body of published work pertains to the effects of aspirin and NSAIDS on gene expression and apoptosis in cells of cancerous origin $(26,27)$, experiments often focus on outcomes over hours/days. It was observed that ligand-induced activation of receptor tyrosine kinases is rapid (within minutes); therefore, EGF endocytosis was investigated in the presence of aspirin/salicylates within time frames relevant to EGF signalling and endocytosis.

With respect to the findings presented herein, p38 MAPK was proposed as a potential rapid target, based on previously published work. Cyclin D1 is overexpressed in cells with EGFR mutations (94). It has previously been reported that, in SW480 cells treated with F-DiA, cyclin D1 
A
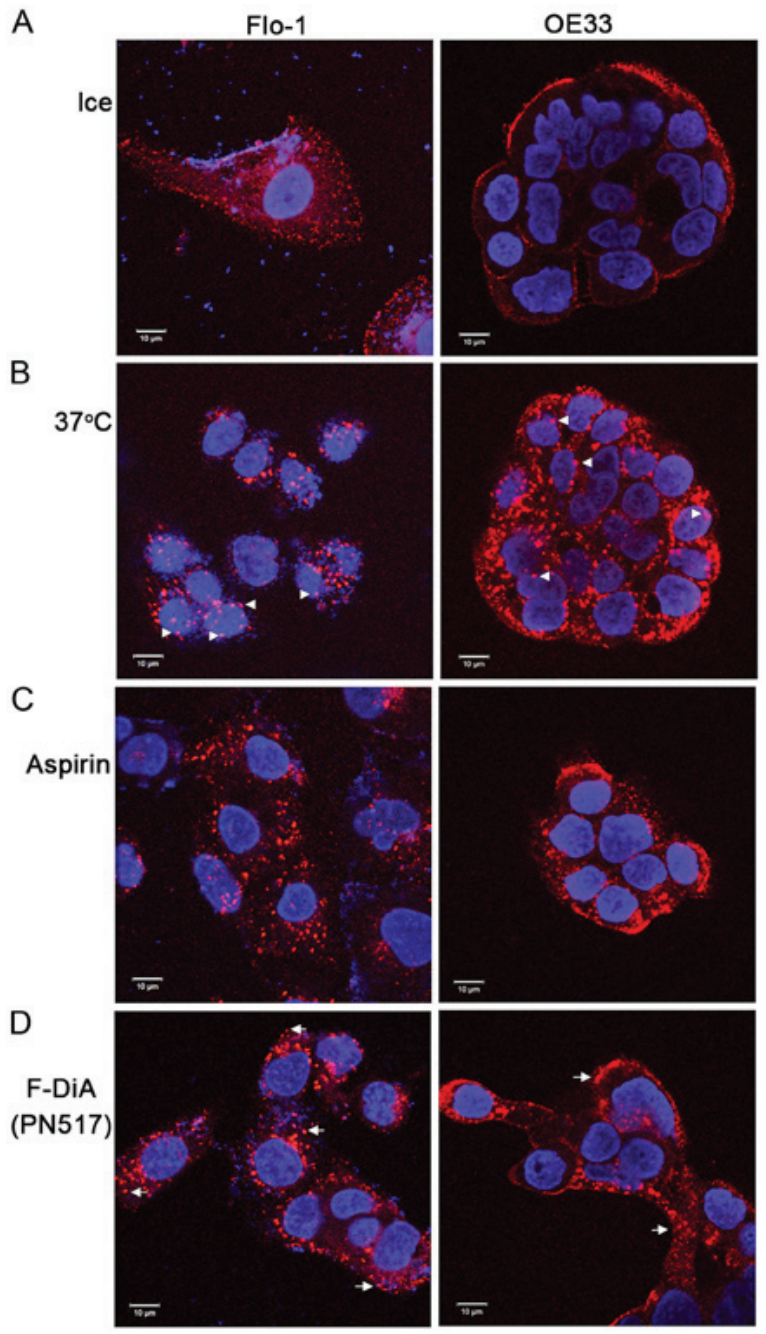

Figure 8. Effect of aspirin analogues under HEPES-buffered conditions on EGF $(20 \mathrm{ng} / \mathrm{ml})$ internalisation in Flo-1 and OE33 oesophageal cell lines. Confocal analysis of oesophageal cancer cells incubated with $(0.5 \mathrm{mM})$ or without compound and fluorescence-conjugated EGF. (A) Negative control, without EGF internalisation in the absence of compound. Cells warmed to $37^{\circ} \mathrm{C}$ in (B) the absence of compound and the presence of (C) aspirin and (D) F-DiA. Images were acquired at $405 \mathrm{~nm}$ for DAPI nucleic stain (blue) and at $561 \mathrm{~nm}$ for Alexa Fluor 555-EGF (red). Representative images were recorded at x40 magnification using an oil/1.30 NA oil immersion objective lens. The close proximity of EGF towards the nucleus upon internalisation with warming is observed in Flo-1 cells (arrowheads). In cells incubated with compound the EGF is less centrally located (arrows), particularly with F-DiA in Flo-1 cells. EGF, epidermal growth factor; F-DiA, fumaryldiaspirin.

levels are significantly reduced and $\mathrm{NF}-\kappa \mathrm{B}$ signalling is attenuated (27). It has previously been reported that cyclin D1 is reduced in CRC cells treated with aspirin, a phenomenon which has been reported to occur in response to p38 MAPK activation within minutes (95). Furthermore, salicylate exposure to COS-1 cells (58) can activate p38 MAPK also within minutes. A number of studies have implicated p38 MAPK as regulator of endocytic trafficking $(96,97)$ and EGFR internalisation (98). p38 MAPK can regulate mu opioid receptor endocytosis, with the early endosomal antigen EEA1 identified as a substrate for p38 MAPK, which impacts on Rab5 activity regulating endocytosis (99). It is suggested that the rapid dysregulation of endocytosis is caused by salicylates and aspirin rapidly activating p38 MAPK and disrupting receptor trafficking, perturbing EGF

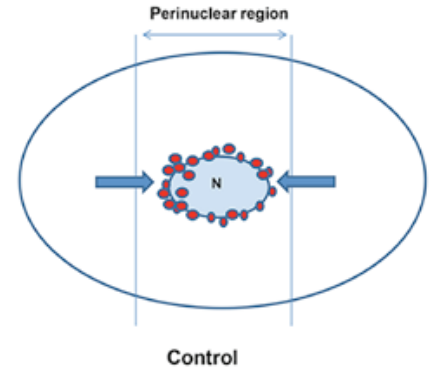

- egr $\bigcirc$ nucleus $\bigcirc$ cytoplasm

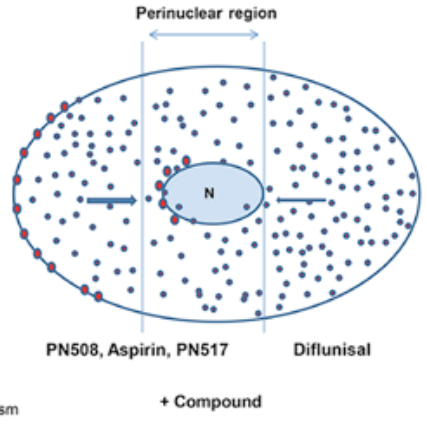

Figure 9. Schematic illustration of the effects of compounds on EGF internalisation. EGF, epidermal growth factor.

signalling and ultimately controlling cyclin D1 levels. This may be facilitated by salicylate persisting/accumulating as a result of its long half-life determined by pharmacokinetics analysis (100), and inhibition of NF- $\mathrm{NB}$ and further known downstream targets. The relatively long half-life of salicylate may be relevant to the chemopreventive nature of low-dose aspirin: Accumulation in tissue reduces inflammation and may further attenuate EGF signalling. These findings suggest that aspirin and salicylates may be useful in cancer treatment, where EGFR amplification, overexpression and constitutive activation in a cancer is notable, e.g., in glioblastoma (101).

With respect to the question of non-salicylate NSAIDs also impacting on the EGFR signalling pathway, notwithstanding concerns regarding conflicting evidence regarding the efficacy of other NSAIDs (in comparison with aspirin) in reducing human cancer risk, e.g., in breast cancer (102), the evidence in the literature to date, as far as we are aware, other than work focused on sulindac affecting EGFR activation/inhibition, directly is limited. There are, however, reports of interrelationships between EGFR and PGE2: for example, activation of EGFR by EGF has been reported to stimulate PGE2 production (103).

Given the fundamental role of EGF signalling in cancer biology, the findings reported in the present study have relevance to the understanding of the chemopreventive activity of aspirin, particularly with respect to COX-independent pharmacology. A schematic illustration of the effect of selected compounds on EGF internalisation is presented in Fig. 9, based upon the representation of the endosomal system by Taub et al (55). It is suggested that further research is required to evaluate the rapid effect of salicylates on the EGFR axis, with a focus on MAPK activation and EGF/EGFR trafficking and phosphorylation. Furthermore, experimentation on EGF signalling in normal tissues exposed to aspirin or diflunisal is required to establish the physiological relevance of the observations reported herein. An analysis of the response of other growth factors and their cognate ligands to physiological concentrations of salicylates, with a particular emphasis on growth factor trafficking and recycling, appears timely. From a biochemical perspective, salicylate is a lipophilic monohydroxybenzoic acid that can interact with lipid membranes $(104,105)$. It is also conceivable that interference of salicylates with membrane structure may affect endocytosis (106). 


\section{Acknowledgements}

The authors wish to thank Dr Michael Cornes (New Cross Hospital, Wolverhampton, UK) for discussions regarding hydrolysis of aspirin analogues and Ms Clare Murcott (Faculty of Science and Engineering, University of Wolverhampton, Wolverhampton, UK) for assistance with confocal microscopy.

\section{Funding}

The present study was supported by the Research Institute in Healthcare Science at the University of Wolverhampton (Wolverhampton, UK).

\section{Availability of data and materials}

The analysed data sets generated during the study are available from the corresponding author on reasonable request.

\section{Authors' contributions}

All the authors have read and approved the final version of this manuscript. AIJB, CSK, STS, CJP and IDN designed and performed the experiments, analysed the data and wrote the manuscript. RMN wrote the Python program for proximity and density quotient analysis, and SJ contributed to data analysis and manuscript preparation.

\section{Ethics approval and consent to participate}

Not applicable.

\section{Patient consent for publication}

Not applicable.

\section{Competing interests}

CJP and IDN are named inventors for a patent for fumaryldiaspirin as an anti-colorectal cancer agent (US patent no. 9351980).

\section{References}

1. Garcia-Albeniz X and Chan AT: Aspirin for the prevention of colorectal cancer. Best Pract Res Clin Gastroenterol 25: 461-472, 2011.

2. Sung JJ, Lau JY, Goh KL and Leung WK; Asia Pacific Working Group on Colorectal Cancer: Increasing incidence of colorectal cancer in Asia: Implications for screening. Lancet Oncol 6: 871-876, 2005

3. Kuriki K and Tajima K: The increasing incidence of colorectal cancer and the preventive strategy in Japan. Asian Pac J Cancer Prev 7: 495-501, 2006.

4. Siegel RL, Fedewa SA, Anderson WF, Miller KD, Ma J, Rosenberg PS and Jemal A: Colorectal Cancer Incidence Patterns in the United States, 1974-2013. J Natl Cancer Inst 109: djw322, 2017.

5. Shaheen NJ, Straus WL and Sandler RS: Chemoprevention of gastrointestinal malignancies with nonsteroidal antiinflammatory drugs. Cancer 94: 950-963, 2002.

6. Sandler RS, Halabi S, Baron JA, Budinger S, Paskett E, Keresztes R, Petrelli N, Pipas JM, Karp DD, Loprinzi CL, et al: A randomized trial of aspirin to prevent colorectal adenomas in patients with previous colorectal cancer. N Engl J Med 348: $883-890,2003$
7. Chan AT, Arber N, Burn J, Chia WK, Elwood P, Hull MA, Logan RF, Rothwell PM, Schrör K and Baron JA: Aspirin in the chemoprevention of colorectal neoplasia: An overview. Cancer Prev Res (Phila) 5: 164-178, 2012.

8. Bibbins-Domingo K and Force USPST; U.S. Preventive Services Task Force: Aspirin Use for the Primary Prevention of Cardiovascular Disease and Colorectal Cancer: U.S. Preventive Services Task Force Recommendation Statement. Ann Intern Med 164: 836-845, 2016.

9. Liao X, Lochhead P, Nishihara R, Morikawa T, Kuchiba A, Yamauchi M, Imamura Y, Qian ZR, Baba Y, Shima K, et al: Aspirin use, tumor PIK3CA mutation, and colorectal-cancer survival. N Engl J Med 367: 1596-1606, 2012.

10. Liggett JL, Zhang X, Eling TE and Baek SJ: Anti-tumor activity of non-steroidal anti-inflammatory drugs: Cyclooxygenase-independent targets. Cancer Lett 346: 217-224, 2014.

11. Thun MJ, Henley SJ and Patrono C: Nonsteroidal anti-inflammatory drugs as anticancer agents: Mechanistic, pharmacologic, and clinical issues. J Natl Cancer Inst 94: 252-266, 2002.

12. Brown JR and DuBois RN: COX-2: A molecular target for colorectal cancer prevention. J Clin Oncol 23: 2840-2855, 2005.

13. Chan AT, Ogino S and Fuchs CS: Aspirin and the risk of colorectal cancer in relation to the expression of COX-2. N Engl J Med 356: 2131-2142, 2007.

14. Bos CL, Kodach LL, van den Brink GR, Diks SH, van Santen MM, Richel DJ, Peppelenbosch MP and Hardwick JC: Effect of aspirin on the Wnt/beta-catenin pathway is mediated via protein phosphatase 2A. Oncogene 25: 6447-6456, 2006.

15. Kopp E and Ghosh S: Inhibition of NF-kappa B by sodium salicylate and aspirin. Science 265: 956-959, 1994.

16. Xu XM, Sansores-Garcia L, Chen XM, Matijevic-Aleksic N, Du M and Wu KK: Suppression of inducible cyclooxygenase 2 gene transcription by aspirin and sodium salicylate. Proc Natl Acad Sci USA 96: 5292-5297, 1999.

17. Yin MJ, Yamamoto Y and Gaynor RB: The anti-inflammatory agents aspirin and salicylate inhibit the activity of I(kappa)B kinase-beta. Nature 396: 77-80, 1998.

18. Goel A, Chang DK, Ricciardiello L, Gasche C and Boland CR: A novel mechanism for aspirin-mediated growth inhibition of human colon cancer cells. Clin Cancer Res 9: 383-390, 2003.

19. Rüschoff J, Wallinger S, Dietmaier W, Bocker T, Brockhoff G, Hofstädter F and Fishel R: Aspirin suppresses the mutator phenotype associated with hereditary nonpolyposis colorectal cancer by genetic selection. Proc Natl Acad Sci USA 95: 11301-11306, 1998.

20. Din FV, Valanciute A, Houde VP, Zibrova D, Green KA, Sakamoto K, Alessi DR and Dunlop MG: Aspirin inhibits mTOR signaling, activates AMP-activated protein kinase, and induces autophagy in colorectal cancer cells. Gastroenterology 142: 1504-1515.e3, 2012.

21. Hawley SA, Fullerton MD, Ross FA, Schertzer JD, Chevtzoff C, Walker KJ, Peggie MW, Zibrova D, Green KA, Mustard KJ, et al: The ancient drug salicylate directly activates AMP-activated protein kinase. Science 336: 918-922, 2012.

22. Shirakawa K, Wang L, Man N, Maksimoska J, Sorum AW, Lim HW, Lee IS, Shimazu T, Newman JC, Schröder S, et al: Salicylate, diflunisal and their metabolites inhibit CBP/p300 and exhibit anticancer activity. Elife 5: pii: e11156, 2016.

23. Pangburn HA, Kraus H, Ahnen DJ and Rice PL: Sulindac metabolites inhibit epidermal growth factor receptor activation and expression. J Carcinog 4: 16, 2005.

24. Selvendiran K, Bratasz A, Tong L, Ignarro LJ and Kuppusamy P: NCX-4016, a nitro-derivative of aspirin, inhibits EGFR and STAT3 signaling and modulates Bcl-2 proteins in cisplatin-resistant human ovarian cancer cells and xenografts. Cell Cycle 7: 81-88, 2008

25. Cho M, Kabir SM, Dong Y, Lee E, Rice VM, Khabele D and Son DS: Aspirin Blocks EGF-stimulated Cell Viability in a COX-1 Dependent Manner in Ovarian Cancer Cells. J Cancer 4: 671-678, 2013.

26. Deb J, Dibra H, Shan S, Rajan S, Manneh J, Kankipati CS, Perry CJ and Nicholl ID: Activity of aspirin analogues and vanillin in a human colorectal cancer cell line. Oncol Rep 26: 557-565, 2011.

27. Claudius AK, Kankipati CS, Kilari RS, Hassan S, Guest K, Russell ST, Perry CJ, Stark LA and Nicholl ID: Identification of aspirin analogues that repress NF- $\kappa \mathrm{B}$ signalling and demonstrate anti-proliferative activity towards colorectal cancer in vitro and in vivo. Oncol Rep 32: 1670-1680, 2014. 
28. Ahmed D, Eide PW, Eilertsen IA, Danielsen SA, Eknæs M, Hektoen M, Lind GE and Lothe RA: Epigenetic and genetic features of 24 colon cancer cell lines. Oncogenesis 2: e71, 2013.

29. Shigeta K, Hayashida T, Hoshino Y, Okabayashi K, Endo T, Ishii Y, Hasegawa $\mathrm{H}$ and Kitagawa Y: Expression of epidermal growth factor receptor detected by cetuximab indicates its efficacy to inhibit in vitro and in vivo proliferation of colorectal cancer cells. PLoS One 8: e66302, 2013.

30. Richter M, Weiss M, Weinberger I, Fürstenberger G and Marian B: Growth inhibition and induction of apoptosis in colorectal tumor cells by cyclooxygenase inhibitors. Carcinogenesis 22: 17-25, 2001.

31. Lin PC, Lin YJ, Lee CT, Liu HS and Lee JC: Cyclooxygenase-2 expression in the tumor environment is associated with poor prognosis in colorectal cancer patients. Oncol Lett 6: 733-739, 2013.

32. Werner S and Grose R: Regulation of wound healing by growth factors and cytokines. Physiol Rev 83: 835-870, 2003.

33. Boonstra JJ, van Marion R, Beer DG, Lin L, Chaves P, Ribeiro C, Pereira AD, Roque L, Darnton SJ, Altorki NK, et al: Verification and unmasking of widely used human esophageal adenocarcinoma cell lines. J Natl Cancer Inst 102: 271-274, 2010.

34. Cheong E, Ivory K, Doleman J, Parker ML, Rhodes M and Johnson IT: Synthetic and naturally occurring COX-2 inhibitors suppress proliferation in a human oesophageal adenocarcinoma cell line (OE33) by inducing apoptosis and cell cycle arrest Carcinogenesis 25: 1945-1952, 2004.

35. Song S, Honjo S, Jin J, Chang SS, Scott AW, Chen Q, Kalhor N, Correa AM, Hofstetter WL, Albarracin CT, et al: The Hippo Coactivator YAP1 Mediates EGFR Overexpression and Confers Chemoresistance in Esophageal Cancer. Clin Cancer Res 21: 2580-2590, 2015.

36. Bosetti C, Talamini R, Franceschi S, Negri E, Garavello W and La Vecchia C: Aspirin use and cancers of the upper aerodigestive tract. Br J Cancer 88: 672-674, 2003.

37. Bosetti C, Gallus S and La Vecchia C: Aspirin and cancer risk: An updated quantitative review to 2005. Cancer Causes Control 17: 871-888, 2006

38. Mosmann T: Rapid colorimetric assay for cellular growth and survival: Application to proliferation and cytotoxicity assays. J Immunol Methods 65: 55-63, 1983.

39. Carmichael J, DeGraff WG, Gazdar AF, Minna JD and Mitchell JB: Evaluation of a tetrazolium-based semiautomated colorimetric assay: Assessment of chemosensitivity testing. Cancer Res 47: 936-942, 1987.

40. Laemmli UK: Cleavage of structural proteins during the assembly of the head of bacteriophage T4. Nature 227: 680-685, 1970.

41. Jiang X, Huang F, Marusyk A and Sorkin A: Grb2 regulates internalization of EGF receptors through clathrin-coated pits. Mol Biol Cell 14: 858-870, 2003.

42. Huang F, Khvorova A, Marshall W and Sorkin A: Analysis of clathrin-mediated endocytosis of epidermal growth factor receptor by RNA interference. J Biol Chem 279: 16657-16661, 2004.

43. Carpenter AE, Jones TR, Lamprecht MR, Clarke C, Kang IH, Friman O, Guertin DA, Chang JH, Lindquist RA, Moffat J, et al CellProfiler: Image analysis software for identifying and quantifying cell phenotypes. Genome Biol 7: R100, 2006.

44. Bordwell FG and Boutan PJ: Conjugative Effects in Divalent Sulfur Groupings ${ }^{1}$. J Am Chem Soc 78: 854-860, 1956.

45. Nelander L, Johansson G, Toplin I, Melera A and Nilsson L: The heats of hydrolysis of aspirin, thioaspirin, and their p-analogues. Acta Chem Scand 18: 973-984, 1964.

46. Schneider MR and Wolf E: The epidermal grow th factor receptor ligands at a glance. J Cell Physiol 218: 460-466, 2009.

47. Yarden Y: The EGFR family and its ligands in human cancer signalling mechanisms and therapeutic opportunities. Eur J Cancer 37 (Suppl 4): S3-S8, 2001

48. Radinsky R, Risin S, Fan D, Dong Z, Bielenberg D, Bucana CD and Fidler IJ: Level and function of epidermal growth factor receptor predict the metastatic potential of human colon carcinoma cells. Clin Cancer Res 1: 19-31, 1995.

49. Voldborg BR, Damstrup L, Spang-Thomsen M and Poulsen HS Epidermal growth factor receptor (EGFR) and EGFR mutations, function and possible role in clinical trials. Ann Oncol 8: 1197-1206, 1997.

50. Citri A and Yarden Y: EGF-ERBB signalling: Towards the systems level. Nat Rev Mol Cell Biol 7: 505-516, 2006.
51. Spano JP, Lagorce C, Atlan D, Milano G, Domont J, Benamouzig R, Attar A, Benichou J, Martin A, Morere JF, et al: Impact of EGFR expression on colorectal cancer patient prognosis and survival. Ann Oncol 16: 102-108, 2005.

52. Normanno N, De Luca A, Bianco C, Strizzi L, Mancino M, Maiello MR, Carotenuto A, De Feo G, Caponigro F and Salomon DS: Epidermal growth factor receptor (EGFR) signaling in cancer. Gene 366: 2-16, 2006.

53. Shostak K and Chariot A: EGFR and NF- $\mathrm{BB}$ : Partners in cancer. Trends Mol Med 21: 385-393, 2015.

54. Habib AA, Chatterjee S, Park SK, Ratan RR, Lefebvre S and Vartanian T: The epidermal growth factor receptor engages receptor interacting protein and nuclear factor-kappa $B$ (NF-kappa B)-inducing kinase to activate NF-kappa B. Identification of a novel receptor-tyrosine kinase signalosome. J Biol Chem 276: 8865-8874, 2001

55. Taub N, Teis D, Ebner HL, Hess MW and Huber LA: Late endosomal traffic of the epidermal growth factor receptor ensures spatial and temporal fidelity of mitogen-activated protein kinase signaling. Mol Biol Cell 18: 4698-4710, 2007.

56. Murphy JE, Padilla BE, Hasdemir B, Cottrell GS and Bunnett NW: Endosomes: A legitimate platform for the signaling train. Proc Natl Acad Sci USA 106: 17615-17622, 2009.

57. Din FV, Dunlop MG and Stark LA: Evidence for colorectal cancer cell specificity of aspirin effects on NF kappa B signalling and apoptosis. Br J Cancer 91: 381-388, 2004.

58. Schwenger P, Bellosta P, Vietor I, Basilico C, Skolnik EY and Vilcek J: Sodium salicylate induces apoptosis via p38 mitogen-activated protein kinase but inhibits tumor necrosis factor-induced c-Jun N-terminal kinase/stress-activated protein kinase activation. Proc Natl Acad Sci USA 94: 2869-2873, 1997.

59. Frantz B, O'Neill EA, Ghosh S and Kopp E: The effect of sodium salicylate and aspirin on NF-kappa B. Science 270: 2017-2019, 1995.

60. Amann R and Peskar BA: Anti-inflammatory effects of aspirin and sodium salicylate. Eur J Pharmacol 447: 1-9, 2002.

61. Nordt SP, Clark RF, Castillo EM and Guss DA: Comparison of three aspirin formulations in human volunteers. West J Emerg Med 12: 381-385, 2011.

62. Borthwick GM, Johnson AS, Partington M, Burn J, Wilson R and Arthur HM: Therapeutic levels of aspirin and salicylate directly inhibit a model of angiogenesis through a Cox-independent mechanism. FASEB J 20: 2009-2016, 2006

63. Dawson JP, Berger MB, Lin CC, Schlessinger J, Lemmon MA and Ferguson KM: Epidermal growth factor receptor dimerization and activation require ligand-induced conformational changes in the dimer interface. Mol Cell Biol 25: 7734-7742, 2005.

64. Hubbard SR and Miller WT: Receptor tyrosine kinases: Mechanisms of activation and signaling. Curr Opin Cell Biol 19: 117-123, 2007.

65. Arkhipov A, Shan Y, Das R, Endres NF, Eastwood MP, Wemmer DE, Kuriyan J and Shaw DE: Architecture and membrane interactions of the EGF receptor. Cell 152: 557-569, 2013.

66. Lemmon MA and Schlessinger J: Cell signaling by receptor tyrosine kinases. Cell 141: 1117-1134, 2010.

67. Huang $\mathrm{L}$ and $\mathrm{Fu} \mathrm{L}$ : Mechanisms of resistance to EGFR tyrosine kinase inhibitors. Acta Pharm Sin B 5: 390-401, 2015.

68. Sigismund S, Woelk T, Puri C, Maspero E, Tacchetti C, Transidico P, Di Fiore PP and Polo S: Clathrin-independent endocytosis of ubiquitinated cargos. Proc Natl Acad Sci USA 102: 2760-2765, 2005

69. Sigismund S, Argenzio E, Tosoni D, Cavallaro E, Polo S and Di Fiore PP: Clathrin-mediated internalization is essential for sustained EGFR signaling but dispensable for degradation. Dev Cell 15: 209-219, 2008.

70. Barbieri E, Di Fiore PP and Sigismund S: Endocytic control of signaling at the plasma membrane. Curr Opin Cell Biol 39: 21-27, 2016.

71. Burke P, Schooler K and Wiley HS: Regulation of epidermal growth factor receptor signaling by endocytosis and intracellular trafficking. Mol Biol Cell 12: 1897-1910, 2001.

72. Goh LK, Huang F, Kim W, Gygi S and Sorkin A: Multiple mechanisms collectively regulate clathrin-mediated endocytosis of the epidermal growth factor receptor. J Cell Biol 189: 871-883, 2010.

73. Mellman I and Yarden Y: Endocytosis and cancer. Cold Spring Harb Perspect Biol 5: a016949, 2013.

74. Villaseñor R, Kalaidzidis Y and Zerial M: Signal processing by the endosomal system. Curr Opin Cell Biol 39: 53-60, 2016. 
75. Wang YN, Yamaguchi H, Hsu JM and Hung MC: Nuclear trafficking of the epidermal growth factor receptor family membrane proteins. Oncogene 29: 3997-4006, 2010.

76. Wang YN and Hung MC: Nuclear functions and subcellular trafficking mechanisms of the epidermal growth factor receptor family. Cell Biosci 2: 13, 2012.

77. Wang YN, Lee HH, Lee HJ, Du Y, Yamaguchi H and Hung MC: Membrane-bound trafficking regulates nuclear transport of integral epidermal growth factor receptor (EGFR) and ErbB-2. J Biol Chem 287: 16869-16879, 2012.

78. Brand TM, Iida M, Li C and Wheeler DL: The nuclear epidermal growth factor receptor signaling network and its role in cancer. Discov Med 12: 419-432, 2011.

79. Jovic M, Sharma M, Rahajeng J and Caplan S: The early endosome: A busy sorting station for proteins at the crossroads. Histol Histopathol 25: 99-112, 2010.

80.Pálfy M, Reményi A and Korcsmáros T: Endosomal crosstalk: Meeting points for signaling pathways. Trends Cell Biol 22: 447-456, 2012.

81. Henriksen L, Grandal MV, Knudsen SL, van Deurs B and Grøvdal LM: Internalization mechanisms of the epidermal growth factor receptor after activation with different ligands. PLoS One 8: e58148, 2013.

82. Capuani F, Conte A, Argenzio E, Marchetti L, Priami C, Polo S, Di Fiore PP, Sigismund S and Ciliberto A: Quantitative analysis reveals how EGFR activation and downregulation are coupled in normal but not in cancer cells. Nat Commun 6: 7999, 2015.

83.Pennock S and Wang Z: A tale of two Cbls: Interplay of c-Cbl and Cbl-b in epidermal growth factor receptor downregulation. Mol Cell Biol 28: 3020-3037, 2008.

84. Rojas M, Yao S and Lin YZ: Controlling epidermal growth factor (EGF)-stimulated Ras activation in intact cells by a cell-permeable peptide mimicking phosphorylated EGF receptor. J Biol Chem 271: 27456-27461, 1996.

85. Nyati MK, Morgan MA, Feng FY and Lawrence TS: Integration of EGFR inhibitors with radiochemotherapy. Nat Rev Cancer 6: 876-885, 2006.

86. Downward J, Waterfield MD and Parker PJ: Autophosphorylation and protein kinase $\mathrm{C}$ phosphorylation of the epidermal growth factor receptor. Effect on tyrosine kinase activity and ligand binding affinity. J Biol Chem 260: 14538-14546, 1985.

87. Keilhack H, Tenev T, Nyakatura E, Godovac-Zimmermann J, Nielsen L, Seedorf K and Böhmer FD: Phosphotyrosine 1173 mediates binding of the protein-tyrosine phosphatase SHP-1 to the epidermal growth factor receptor and attenuation of receptor signaling. J Biol Chem 273: 24839-24846, 1998.

88. Hsu JM, Chen CT, Chou CK, Kuo HP, Li LY, Lin CY, Lee HJ, Wang YN, Liu M, Liao HW, et al: Crosstalk between Arg 1175 methylation and Tyr 1173 phosphorylation negatively modulates EGFR-mediated ERK activation. Nat Cell Biol 13: 174-181, 2011.

89.Li H, Zhu F, Boardman LA, Wang L, Oi N, Liu K, Li X, Fu Y, Limburg PJ, Bode AM, et al: Aspirin Prevents Colorectal Cancer by Normalizing EGFR Expression. EBioMedicine 2: 447-455, 2015.

90. Murthy U, Basu M, Sen-Majumdar A and Das M: Perinuclear location and recycling of epidermal growth factor receptor kinase: Immunofluorescent visualization using antibodies directed to kinase and extracellular domains. J Cell Biol 103 333-342, 1986.

91. Kesarwala AH, Samrakandi MM and Piwnica-Worms D: Proteasome inhibition blocks ligand-induced dynamic processing and internalization of epidermal growth factor receptor via altered receptor ubiquitination and phosphorylation. Cancer Res 69: 976-983, 2009.
92. Farrow DC, Vaughan TL, Hansten PD, Stanford JL, Risch HA, Gammon MD, Chow WH, Dubrow R, Ahsan H, Mayne ST, et al: Use of aspirin and other nonsteroidal anti-inflammatory drugs and risk of esophageal and gastric cancer. Cancer Epidemiol Biomarkers Prev 7: 97-102, 1998.

93. Funkhouser EM and Sharp GB: Aspirin and reduced risk of esophageal carcinoma. Cancer 76: 1116-1119, 1995.

94. Kobayashi S, Shimamura T, Monti S, Steidl U, Hetherington CJ, Lowell AM, Golub T, Meyerson M, Tenen DG, Shapiro GI, et al: Transcriptional profiling identifies cyclin D1 as a critical downstream effector of mutant epidermal growth factor receptor signaling. Cancer Res 66: 11389-11398, 2006.

95. Thoms HC, Dunlop MG and Stark LA: p38-mediated inactivation of cyclin D1/cyclin-dependent kinase 4 stimulates nucleolar translocation of RelA and apoptosis in colorectal cancer cells. Cancer Res 67: 1660-1669, 2007.

96. Cavalli V, Vilbois F, Corti M, Marcote MJ, Tamura K, Karin M, Arkinstall S and Gruenberg J: The stress-induced MAP kinase p38 regulates endocytic trafficking via the GDI:Rab5 complex. Mol Cell 7: 421-432, 2001.

97. Fratti RA, Chua J and Deretic V: Induction of p38 mitogen-activated protein kinase reduces early endosome autoantigen 1 (EEA1) recruitment to phagosomal membranes. J Biol Chem 278: 46961-46967, 2003.

98. Vergarajauregui S, San Miguel A and Puertollano R: Activation of p38 mitogen-activated protein kinase promotes epidermal growth factor receptor internalization. Traffic 7: 686-698, 2006.

99. Macé G, Miaczynska M, Zerial $M$ and Nebreda AR: Phosphorylation of EEA1 by p38 MAP kinase regulates mu opioid receptor endocytosis. EMBO J 24: 3235-3246, 2005.

100.Higgs GA, Salmon JA, Henderson B and Vane JR: Pharmacokinetics of aspirin and salicylate in relation to inhibition of arachidonate cyclooxygenase and antiinflammatory activity. Proc Natl Acad Sci USA 84: 1417-1420, 1987.

101. Hatanpaa KJ, Burma S, Zhao D and Habib AA: Epidermal growth factor receptor in glioma: Signal transduction, neuropathology, imaging, and radioresistance. Neoplasia 12: 675-684, 2010.

102. Moris D, Kontos M, Spartalis E and Fentiman IS: The Role of NSAIDs in Breast Cancer Prevention and Relapse: Current Evidence and Future Perspectives. Breast Care (Basel) 11: 339-344, 2016

103. Taub M, Parker R, Mathivanan P, Ariff MA and Rudra T: Antagonism of the prostaglandin E2 EP1 receptor in MDCK cells increases growth through activation of Akt and the epidermal growth factor receptor. Am J Physiol Renal Physiol 307: F539-F550, 2014.

104. Barrett MA, Zheng S, Roshankar G, Alsop RJ, Belanger RK, Huynh C, Kučerka N and Rheinstädter MC: Interaction of aspirin (acetylsalicylic acid) with lipid membranes. PLoS One 7: e34357, 2012.

105. Alsop RJ, Toppozini L, Marquardt D, Kučerka N, Harroun TA and Rheinstädter MC: Aspirin inhibits formation of cholesterol rafts in fluid lipid membranes. Biochim Biophys Acta 1848: 805-812, 2015

106. Puri C, Tosoni D, Comai R, Rabellino A, Segat D, Caneva F, Luzzi P, Di Fiore PP and Tacchetti C: Relationships between EGFR signaling-competent and endocytosis-competent membrane microdomains. Mol Biol Cell 16: 2704-2718, 2005.

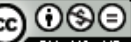

This work is licensed under a Creative Commons

Attribution-NonCommercial-NoDerivatives 4.0 International (CC BY-NC-ND 4.0) License. 